\title{
The Zanclean megaflood of the Mediterranean - Searching for independent evidence
}

\author{
Daniel Garcia-Castellanos ${ }^{\mathrm{a}, *}$, Aaron Micallef ${ }^{\mathrm{b}, \mathrm{c}}$, Ferran Estrada $^{\mathrm{d}}$, Angelo Camerlenghi ${ }^{\mathrm{e}}$, \\ Gemma Ercilla $^{\mathrm{d}}$, Raúl Periáñez ${ }^{\mathrm{f}}$, José María Abril ${ }^{\mathrm{f}}$

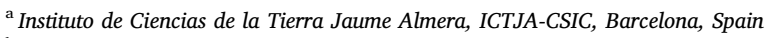 \\ ${ }^{\mathrm{b}}$ Marine Geology and Seafloor Surveying, Department of Geosciences, University of Malta, Msida, MSD 2080, Malta \\ ${ }^{\mathrm{c}}$ Helmholtz Centre for Ocean Research, GEOMAR, Kiel, Germany \\ ${ }^{\mathrm{d}}$ Instituto de Ciencias del Mar, ICM-CSIC, Barcelona, Spain \\ ${ }^{\mathrm{e}}$ Istituto Nazionale di Oceanografia e di Geofisica Sperimentale (OGS), Trieste, Italy \\ ${ }^{\mathrm{f}}$ University of Sevilla, Spain
}

\section{A B S T R A C T}

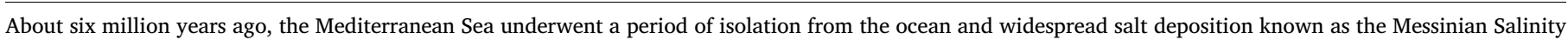

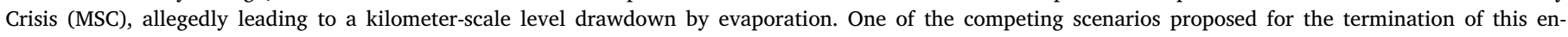

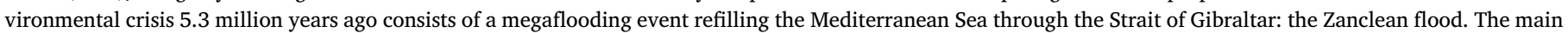

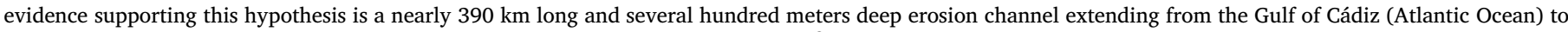

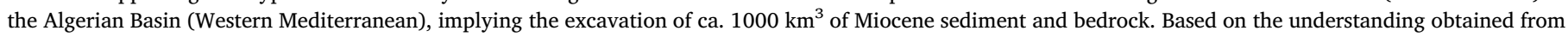

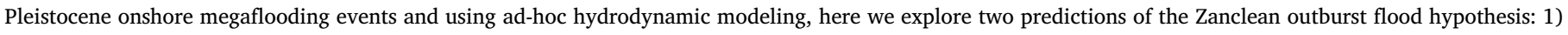

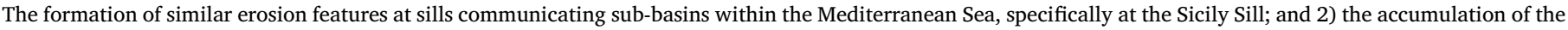

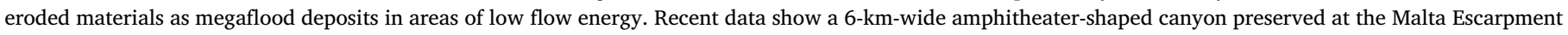

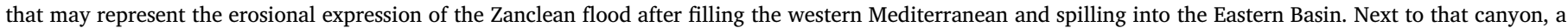

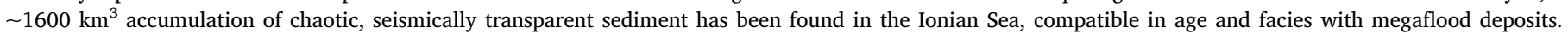

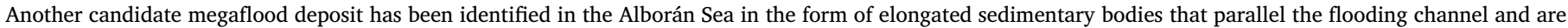

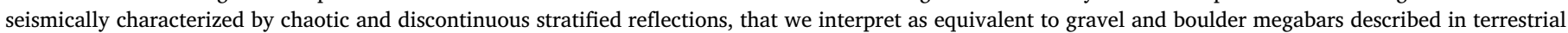

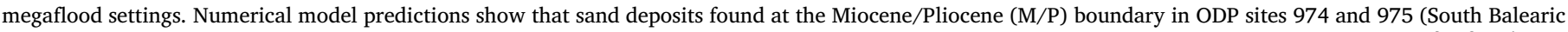
and Tyrrhenian seas) are consistent with suspension transport from the Strait of Gibraltar during a flooding event at a peak water discharge of $\sim 10^{8} \mathrm{~m}^{3} \mathrm{~s}^{-1}$.

\section{A pre-scientific myth about the origin of the Mediterranean Sea}

In his Historia Naturalis ( $\sim 77 \mathrm{AD})$, Pliny the Elder reports on a legend popular among the inhabitants of southern Iberia, telling how the Mediterranean Sea was born. According to this myth, the Mediterranean Sea was deserted and cut-off from the Ocean, and it was Hercules who dug an inlet with his sword between Jebel-el-Mina (Africa) and the rock of Gibraltar (Europe). This allowed the ocean to flow into the Mediterranean Basin, where "it was before excluded", thus "changing the face of Nature". All through the history of western culture, a myriad of later classical writers including Galileo Galilei's Dialogues (1632) or Jacinto Verdaguer's poem Atlàntida (1876) were inspired by Pliny's account, elaborating on the scenario of a desiccated Mediterranean Sea flooded by Atlantic waters. None of these accounts linked explicitly the myth to field evidence. Even after Steno and Lyell set the principles of Geology and the Messinian stage was recognized as a pan-Mediterranean evaporitic phase in the late nineteenth century by Mayer-Eymar in 1867 (Selli, 1960), nobody linked it with Pliny's accounts, perhaps because their catastrophic nature was at odds with the principle of gradualism, a scientific pillar deeply rooted in the birth of Geology.

Gradualism was eventually challenged when Bretz (1925) and Pardee (1942) set the floor for a paradigm change in geology recognizing outburst floods of unprecedented magnitude as the main agent for landscape formation in the Scablands (Washington state, NW USA) during the Pleistocene. Bretz and Pardee described flood deposits, giant erosion coulees and giant 'ripples' that are today widely accepted to be the result of the catastrophic emptying of Lake Missoula in Montana, about seventeen thousand years ago (Benito, 2003).

\footnotetext{
* Corresponding author.

E-mail address: d.g.c@csic.es (D. Garcia-Castellanos).
} 


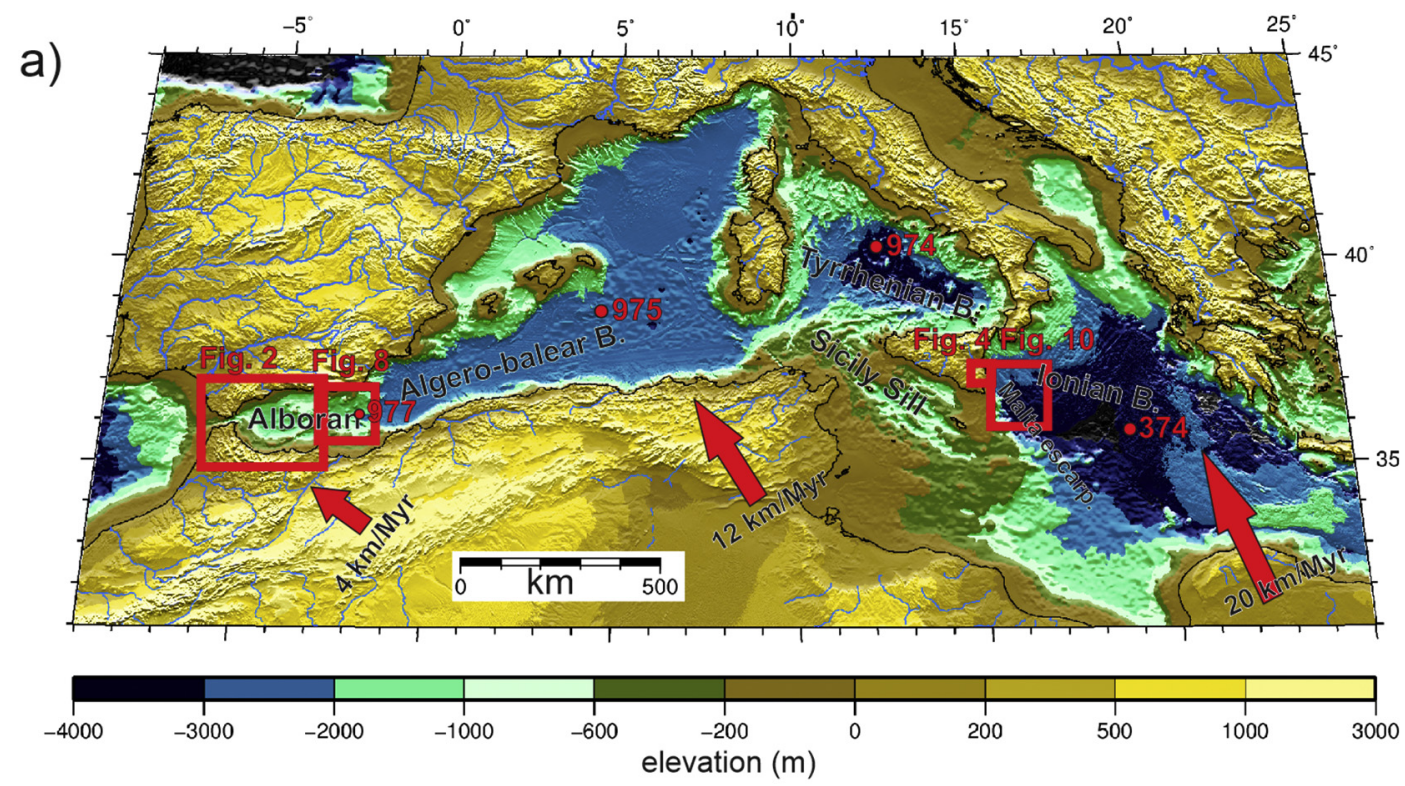

b)

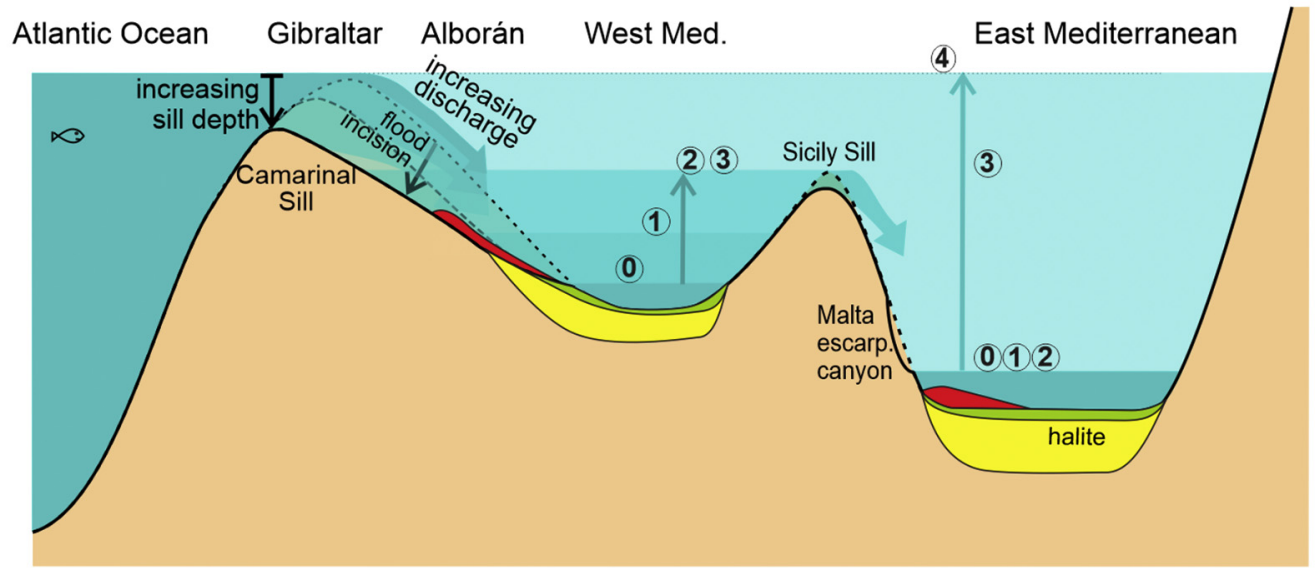

Fig. 1. a) Topographic map of the Ionian Sea and western Mediterranean showing the location of data shown in this article. Red arrows indicate the average motion of Africa relative to Eurasia since 5.3 million years ago. Numbers in red indicate IODP/DSDP drillings mentioned in the text. b) Cartoon (not to scale) showing the timing and the flood erosional and depositional features expected in the eastern and western basins of the Mediterranean as a result of a large water input through the Gibraltar gateway, showing 5 stages: 0) Initial level before significant Atlantic inflow occurred; 1) time of maximum erosion rate at the Strait of Gibraltar; 2) the western basin level reaches the Sicily Sill. 3) eastern basin level reaches the Sicily Sill; and 4) the Mediterranean is filled to the normal oceanic level. The mobile unit (Messinian halite), Lago-Mare, and flood deposits discussed in this study are depicted in yellow, green, and red, respectively. (For interpretation of the references to colour in this figure legend, the reader is referred to the web version of this article.)

\subsection{The development of the Messinian Salinity Crisis theory}

Only in the decade of the 1970's did the hypothesis of a flood ending a Mediterranean desiccation enter the scientific literature, when DSDP drilling confirmed large deposits of evaporites in the deepest regions of the Mediterranean Sea (Hsü et al., 1973b; Ryan et al., 1973). The question as to how did this Messinian Salinity Crisis (MSC) end emerged from the barely $15 \mathrm{~cm} \mathrm{M/P} \mathrm{transition} \mathrm{in} \mathrm{ODP} \mathrm{974B} \mathrm{(Tyrrhenian} \mathrm{Sea;}$ Fig. 1), which meant an "abrupt palaeoceanographic change created by the re-establishment of an open-marine environment in the earliest Pliocene" (Iaccarino and Bossio, 1999). The term flood or reflooding of the Mediterranean became a common place in the scientific literature studying the MSC (Hsü et al., 1973a, b; Comas et al., 1996), although it referred vaguely to a geologically-rapid transition from evaporitic to open marine conditions. Sedimentological analysis of the drilling cores (grain-size and microfauna) cannot resolve gradual changes shorter than a few millimeters in the core (i.e., a few thousand years in duration). For example, based on DSDP sites 121-139, K. J. Hsü et al. (1973a) speculated about a refill of the Mediterranean lasting "probably less than 1000 years". Onshore evidence for a rapid Mediterranean Sea level rise at the end of the MSC came from the abundance of Giberttype deltas in the Gulf of Lyons and the Tyrrhenian Sea (Clauzon, 1978, 1982; Breda et al., 2009) and from the abrupt transit from paleosol to foraminifera-rich, deep marine laminites in the M/P contact in Pissouri (Orszag-Sperber et al., 2000). These observations suggested that the sea level rise was rapid in sedimentological terms and that the Strait of Gibraltar was the scenario for the reconnection between the Atlantic Ocean and the Mediterranean Sea, reestablishing the normal marine conditions ca. 5.3 million years ago.

The main evidence for a restriction from the Ocean and a Mediterranean-wide environmental change is the widespread presence of gypsum deposits along the Mediterranean coast, and a 1 to $3 \mathrm{~km}$ thick layer of halite in the abyssal areas of the Mediterranean, generally interpreted as the result of a severe restriction of the connection to the Atlantic Ocean. This halite layer is outcropping today in Calabria and it is widely present in the subsurface of the Caltanissetta Basin in Sicily, 
where it is commercially exploited in salt mines, and it is conspicuous in the deep Mediterranean basins from marine seismic reflection data (Lofi, 2010, 2018). Its mass had been estimated at $>310^{18} \mathrm{~kg}$ (Blanc, 2000; Ryan, 2009), around $10 \%$ of the salt contained in the global ocean, but a recent study based on a dense compilation of seismic prospection surveys, estimates its volume at only 821 to $92710^{6} \mathrm{~km}^{3}$ of (Haq et al., 2020), ca. 4\% of today's salt dissolved in the ocean.

However, salt precipitation does not necessarily imply a desiccation. Natural salt pans do not require a level drawdown by desiccation in order to accumulate salt; a persistent but restricted connection that allows no outflow of brine but only inflow of normal saline water can lead to salt precipitation with no drawdown (e.g., today's Garabogazköl in Turkmenistan). The main evidence actually supporting a kilometric drawdown for the Mediterranean during the late Neogene is the Mediterranean-wide Messinian Erosion Surface (MES) (Lofi, 2010, 2018) recorded in the seismic stratigraphy of the basin margins.

The Zanclean flood hypothesis is thus entangled with a wider discussion about the MSC: whether there was a kilometric-scale drawdown after the precipitation of the marginal primary gypsum. The Zanclean (5.33 to 3.60 million year ago) is the first stage of the Pliocene and its beginning coincides with the termination of the Messinian (last stage of the Miocene). A megaflood-like termination of the MSC requires a significant drawdown of the Mediterranean level. The occurrence of a significant drawdown of the Mediterranean during the Messinian (be it a full or a partial desiccation) is currently under strong debate and far from a consensus. Let us start summarizing the main reasons that question the kilometric drawdown scenario. A geochemical reexamination of the aforementioned drillings has questioned the shallowwater formation of the deep evaporite cores (Hardie and Lowenstein, 2004). Some studies suggest that the evaporitic deposition occurred under no substantial sea level drawdown but in a deep-basin under deep-water in a deep-basin condition, i.e., in a Mediterranean Sea filled to a level close to today's (e.g., Lugli et al., 2015; Roveri et al., 2001). This model is also supported by the homogeneity of isotopic signatures between distant synchronous gypsum deposits, suggesting a connection between the Mediterranean sub-basins and hence a high water level (García-Veigas et al., 2018).

Questioning a significant lowering of the level of the Mediterranean requires a mechanism to explain the MES alternative to subaerial exposure. The most developed such alternative mechanism so far is the hyperpycnal submarine cascading erosion (Roveri et al., 2014b), according to which the erosion of the margins resulted from sea water currents from the platforms towards the abyssal areas as a result of high density related to evaporation. As for the abrupt M/P transition, the alternative explanation to the Zanclean flood is a density-driven outpumping (Marzocchi et al., 2016) of the Mediterranean Sea. In this model, the Mediterranean level raises due to fresh water inputs from the Paratethys during the Lago-Mare stage, reconnecting and pumping it out to the denser Atlantic Ocean. Salt deposition was followed by a panMediterranean phase of sedimentation in a fresh to brackish water environment, represented by the so-called "Lago-Mare" sedimentary facies, which includes microfossils and ostracods originating from the Paratethys realm (present Carpathian and Black Sea areas) (Krijgsman et al., 2010). This deposition preceded the reestablishment of normal open marine conditions (Zanclean stage), and its presence at nearly the present sea level in outcrops in the margins around the Mediterranean Sea suggests that those fresh/brackish waters were covering a full and connected Mediterranean. However, the nature and environment of this last stage of the MSC are to date far from well understood since it also includes marine fish (Carnevale et al., 2006, 2017).

Studies that argue for a kilometer-scale drawdown (not necessarily implying a full desiccation) place it temporally either following (Escutia and Maldonado, 1992; Ryan, 2008; Estrada et al., 2011; Urgeles et al., 2011) or preceding (Bache et al., 2009, 2015) the precipitation of the 1 $\mathrm{km}$ of halite in the abyssal regions. Within the drawdown hypothesis, the erosional surfaces in the margins of the sea are attributed to subaerial processes such as river incision or wave erosion. Further evidence supporting is based on the relative abundance of volcanic samples dating to the MSC around the Mediterranean, which according to modeling results can be explained by the decompression of the crust due to the removal of the water column (Sternai et al., 2017).

As for the deep geodynamic causes for these changes in oceanic connectivity at the Strait of Gibraltar, computer simulations suggest that desiccation of the basin, as well as its later reflooding at the earliest Pliocene, may have been caused both by the vertical motions related to deep processes in the lithospheric mantle, namely the sink and detachment of a lithospheric slab underneath the Gibraltar Arc (GarciaCastellanos and Villaseñor, 2011; Jiménez-Munt et al., 2019). The combination of these processes with erosion by the inflowing water at the gateway may explain the long initial stage of salt precipitation (gypsum and halite) and an extremely rapid basin refill.

The aim of the present article is to summarize recent and new stratigraphic evidence and modeling results that test the megaflood hypothesis (Garcia-Castellanos et al., 2009). The geophysical data we examine target the erosional and depositional impact of a large water flow entering the Mediterranean through the Alborán Sea and then entering the Eastern Mediterranean over the Malta Escarpment. Because such a megaflooding event would require a significant sea level drawdown in the Mediterranean, we will discuss the implications of the findings for the evolution of the MSC.

\subsection{First models and quantifications of the Zanclean flood}

The quantification of a geologically-rapid refill after the MSC was addressed specifically only in this century, first based on the geomorphology of the Strait of Gibraltar area and then based on geophysical and modeling techniques (Blanc, 2002, 2006; Garcia-Castellanos et al., 2009). According to Blanc (2002), an unprecedented stream shaped the Strait of Gibraltar after a capture of the Atlantic Ocean took place by retrogressive erosion of a river draining into the desiccated Alborán Sea (a process also known as river piracy). Based on assumptions on the size of the gateway during the Late Messinian and on collapse structures near the straits, that study concluded that the refill was cataclysmic, following an "instant breakthrough of the Atlantic waters".

Meanwhile, cores from drilling funded by the Africa-Europe tunnel project (Esteras et al., 2000) showed a > 200 m-deep erosional trough carved in the hard flysch units (Late Cretaceous to Neogene in age) outcropping around the strait. A similar eastward-oriented Pliocene incision is observed further to the east, in the Mediterranean side of the strait (Alborán Sea; Fig. 2). Both features had previously been interpreted as subaerial (fluvial) erosion by a forerunner stream during the Messinian sea level drawdown (Blanc, 2002; Esteras et al., 2000). However, the U-shape of the Messinian erosion surface (MES) in the Alboran Sea, the lack of a significant catchment, and the fact that this erosional channel crosses the natural drainage divide between the Atlantic and the Mediterranean $(80 \mathrm{~km}$ in the Gulf of Cádiz and > $200 \mathrm{~km}$ in the Alborán Basin) argue against subaerial erosion during the MSC drawdown (Garcia-Castellanos et al., 2009). Numerical modeling of this erosion channel assuming that it was excavated by the Atlantic waters overtopping the Strait of Gibraltar, led to estimations of the flood discharge of up to $100 \mathrm{~Sv}$ ( 1 Sverdrup $=10^{6} \mathrm{~m}^{3} \mathrm{~s}^{-1}$ ), with a duration of 2 years or less (Garcia-Castellanos et al., 2009) (see Section 5). The initial stages of the flood, according to that model, may have lasted up to a few thousand years before the inflow of water becomes significant relative to the Mediterranean water balance. By the time the flood overcomes lake evaporation and significantly refills the Mediterranean basin, erosion rates are predicted higher than a few $\mathrm{mm} \mathrm{yr}^{-1}$, preventing any tectonic or eustatic change from closing the seaway again and making the flooding process irreversible. This argues against the possibility of multiple flooding events (Rouchy and Martin, 1992) or against calm periods intercalated during the flood. It conflicts with the interpretation of a ravinement surface in the Gulf of Lions as the 


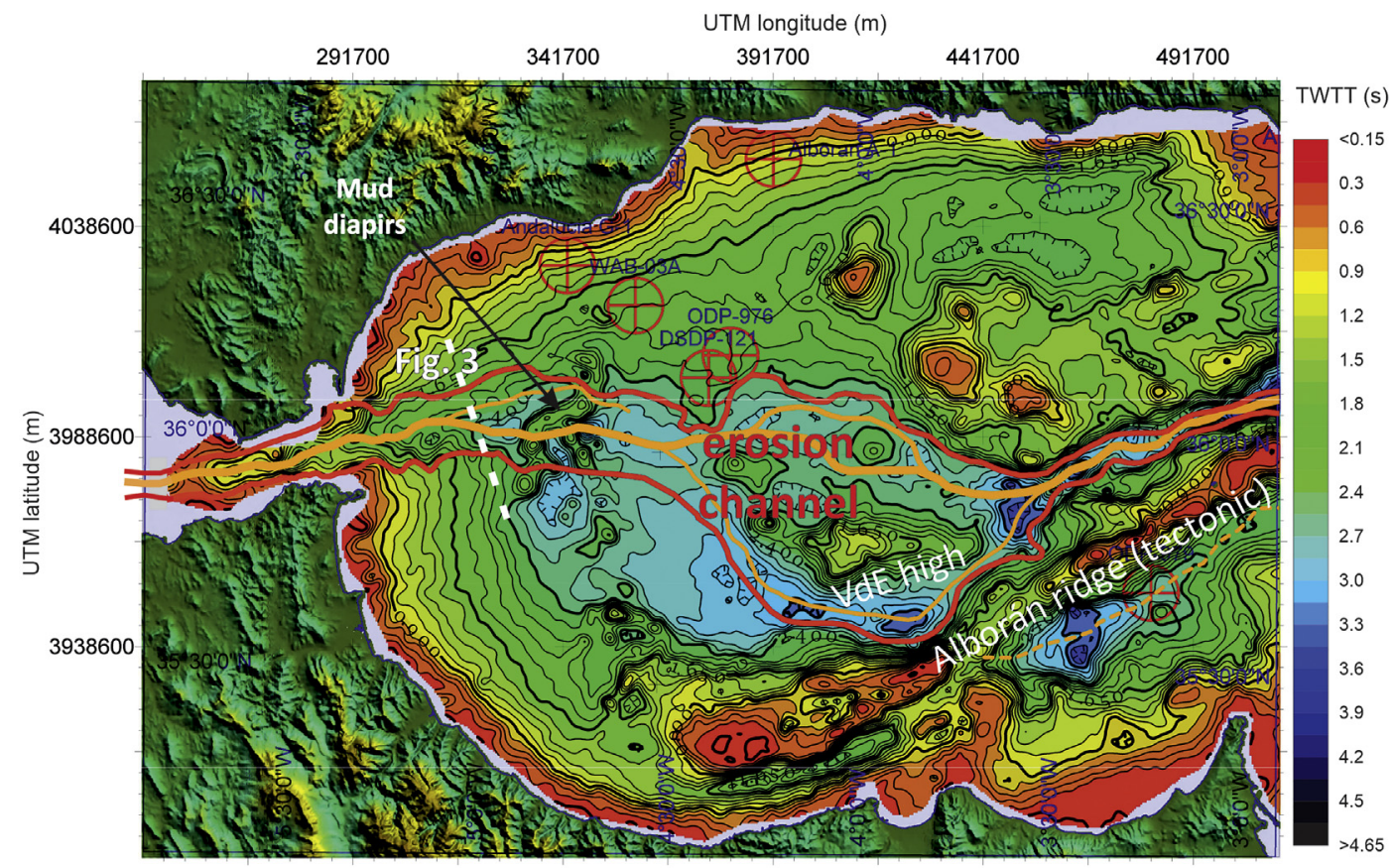

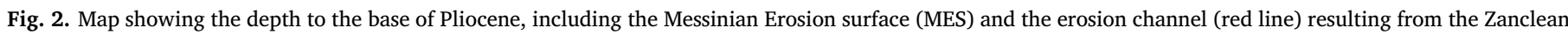

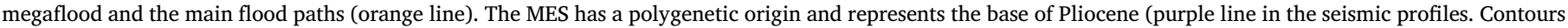

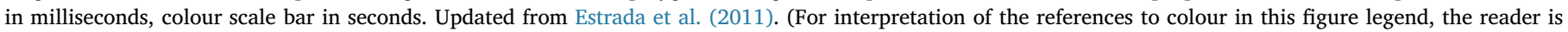
referred to the web version of this article.)

result of wave erosion during the flood (Bache et al., 2009; Estrada et al., 2011) and suggests that this might have been formed during climatically-controlled changes of lake level during the drawdown phase, similar to the wave-cut surfaces in the Malta Escarpment that will be shown below (Micallef et al., 2019). The accelerating flooding rates due to inlet erosion (Garcia-Castellanos et al., 2009) precludes the stagnation of the flooding process once the water discharge has become substantial in comparison with the water budget of the Mediterranean and has significantly risen its level.

In summary, while observations remain unclear on whether the crisis involved an important desiccation of the Mediterranean Sea (necessary condition for a catastrophic flood), models do provide some ideas on how to independently test this scenario. In this article, we summarize recent results from seismic stratigraphy and hydrological modeling assessing two predictions implied by the Zanclean flood thesis: 1) that at a few thousand cubic kilometers of rock eroded from the sills should have deposited elsewhere in the Mediterranean Sea; and 2) that flood erosion and sedimentation patterns similar to those described in Gibraltar should be found near the Sicily Sill, in the area where the flooded western Mediterranean should overspill into the eastern basin.

\section{Flood erosion features}

Apart from the ubiquitous MES discordance in the seismic sedimentary record of the Mediterranean Sea, two erosional features have so far been described that seem incompatible with subaerial exposure during the MSC drawdown or with processes other than an unprecedented discharge of water. One is at the seaway between the Atlantic Ocean and the Mediterranean Sea, and the other at the gateway between the western and eastern Mediterranean basins.

\subsection{Alborán Sea erosive channel}

A remarkable erosive channel has been described in the deepest areas of the Messinian Erosion Surface (MES) of the Alborán Sea, particularly in the vicinity of the Strait of Gibraltar. Fig. 2 shows a significantly updated version of the depth to the MES in this region, based on a more dense and extended seismic reflection database relative to Estrada et al. (2011). The erosion channel is in lateral continuation with the erosional trough incised into the flysch units in the Strait of Gibraltar (Blanc, 2002; Esteras et al., 2000) and extends along $390 \mathrm{~km}$ with a W-E trend from the Gulf of Cádiz (Atlantic Ocean) (Garcia-Castellanos et al., 2009), crossing the deepest parts of the Alborán Sea (Figs. 2 \& 3) until the Algerian Basin. This erosion channel geometry varies from $2 \mathrm{~km}$ width and $>200 \mathrm{~m}$ depth in the Atlantic side (were it dissects the basement) to $>15 \mathrm{~km}$ width and $>500 \mathrm{~m}$ depth in the Alborán Sea (were it erodes Miocene sediment). While Blanc (2002) linked the Atlantic section of this feature to the reflooding of the Mediterranean Sea, its Alborán continuation was linked to subaerial erosion by rivers during the MSC drawdown (Blanc, 2002; Campillo et al., 1992). Later investigations based on a wider geophysical database and numerical modeling lead to the alternative interpretation of an outburst flood erosion due to the breaching of the Straight of Gibraltar (Garcia-Castellanos et al., 2009; Estrada et al., 2011), after which the subsequent flood-retrogressive erosion propagated westwards, $80 \mathrm{~km}$ into the Atlantic domain. This hypothesis is consistent with the channel's U-shaped section, which contrasts with the V-shaped valley associated to fluvial erosion (Fig. 3). It also explains why this erosional feature has continuity westwards from the Strait of Gibraltar into the Gulf of Cádiz, crossing the natural divide formed by the Betic-Rif orogen.

The morphological setting of the Alborán Basin is inherited from Late Neogene E-W extension coeval with African-Eurasian convergence and with volcanism (Duggen et al., 2003). As a result, the relief of the Alborán Basin was already abundant in volcanic seamounts and structural highs (Fig. 2). Adapting to this inherited landscape, the channel splits in two W-E branches only to merge again further to the E (Fig. 2). They are separated by a seamount (the Vizconde de Eza High, VdE in Fig. 2) that may have been a topographic obstacle during the flood. The channel incises vertically up to $600 \mathrm{~m}$ into the upper Miocene deposits, eroding MSC deposits that do not include the halite evaporites (Mobile 


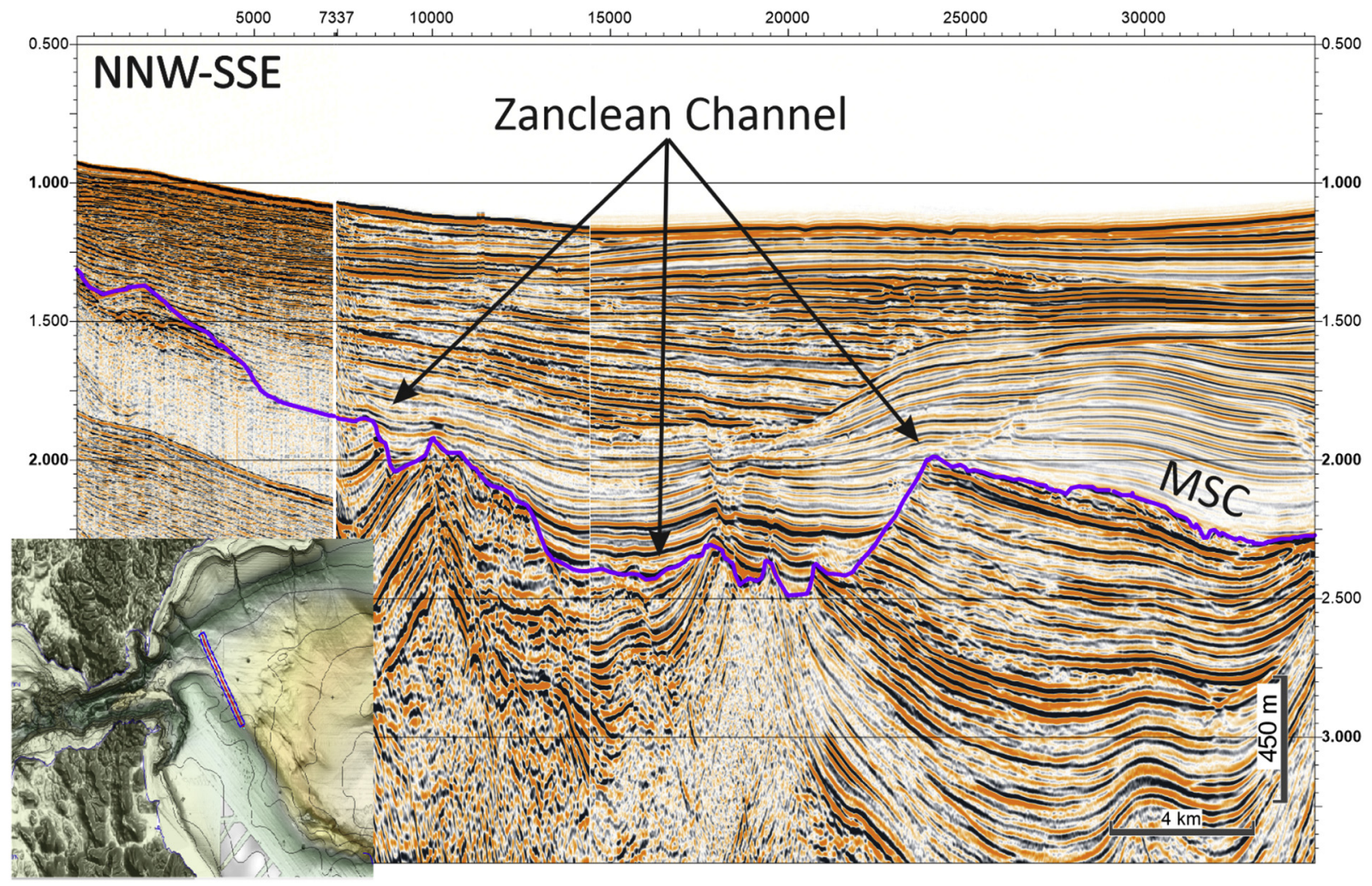

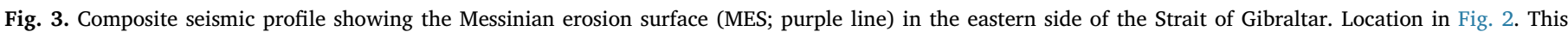

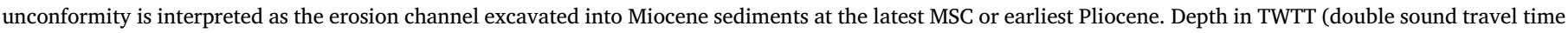

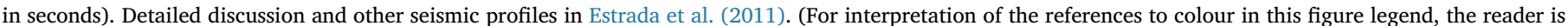
referred to the web version of this article.)

Unit) found in the deeper basins of the Mediterranean. This is probably due to the shallower depth of this basin during that time (e.g., BoothRea et al., 2018). The channel has been subsequently deformed during the Plio-Quaternary by mud diapirism in the Western Alboran Basin and the compressional tectonism as a consequence of the ca. 4-5 $\mathrm{mm} \mathrm{yr}^{-1}$ of the ongoing convergence rate between Africa and Eurasia (Estrada et al., 2018).

\subsection{Amphitheater-headed canyon in the Malta Escarpment}

The Noto Canyon is a ca. $27 \mathrm{~km}$ long, $15 \mathrm{~km}$ wide, and $1.5 \mathrm{~km}$ deep geomorphic feature in the northern Malta Escarpment (SE Sicily margin; Fig. 4) (Micallef et al., 2018). It includes a canyon with a Ushaped cross-section carved in Mesozoic limestone. The head of this canyon has an amphitheater-shaped head, $6 \mathrm{~km}$ in width and $700 \mathrm{~m}$ high. This is very unusual for a submarine canyon and conspicuously different from the other canyons along the escarpment (Micallef et al., 2019). The strike of the Noto Canyon changes by $90^{\circ}$ at a distance of $8 \mathrm{~km}$ upslope from its mouth. The canyon walls have a slope of $70^{\circ}$. Upslope of the Noto Canyon head, the seafloor has a gentler gradient of $7^{\circ}$ and hosts a dendritic network of small tributary canyons. At the base of the Noto Canyon head, a sediment layer 100-200 m thick has accumulated at the bottom of the canyon (Fig. 4b).

The Noto canyon is located next to a set of massive, seismically chaotic to transparent deposits identified through multichannel seismic reflection data in the western Ionian Basin and interpreted as a sedimentary body of up to $860 \mathrm{~m}$ in thickness and $1600 \mathrm{~km}^{3}$ in volume (see next section). Based on the inference that this sedimentary unit is compatible with a megaflood deposit, the Noto Canyon has been interpreted as having formed via excavation by a large subaerial flow of water caused by the overflow of the Western Mediterranean and its spilling into the Eastern Mediterranean basin during Zanclean flood
(Micallef et al., 2018). However, this erosional feature is not directly dated and no stratigraphic correlation exists between its excavation and the Ionian stratigraphy and drillings.

Further to the south along the same escarpment, a series of concave slope breaks is observed at a consistent depth of $2400-2500 \mathrm{~m}$ below present sea level and with a total length of about $100 \mathrm{~km}$ (Fig. 5). These are interpreted as palaeoshorelines and shore platforms excavated by wave erosion related to a lowstand of the Mediterranean Sea below its present sea level (Micallef et al., 2019). An isostatic restoration of those palaeoshorelines and shore platforms on the northern Malta Escarpment suggest an evaporative drawdown of 1800-2000 m below present sea level. While these do not directly support the occurrence of an abrupt outburst flood refilling the eastern Mediterranean, the shorelines do support a large hydraulic head available for the refilling waters pouring into the eastern basin with a flow energy comparable to, if not larger than, that at the Strait of Gibraltar. The bottom of the Noto Canyon (2300-2600 m) is close to the depth of those shorelines and to the base of the megaflood deposit, allowing us to speculate that the canyon may have been excavated after a long period when the level of the Eastern Mediterranean remained at that level. After isostatic restoration by removing the weight of the Plio-Quaternary sediment and the water column (Micallef et al., 2019), the original depth of the base of the canyon the during the MSC would range between 1750 and $2050 \mathrm{~m}$.

\subsection{Hydrodynamic models for the fate of megaflooding sediment}

The erosional channel that runs from the Gulf of Cádiz to the Algerian Basin (Fig. 2) implies the excavation of at least $1000 \mathrm{~km}^{3}$ of Miocene sediment from the Alboran Basin and bedrock (Oligocene flysch) from the Strait of Gibraltar. The submarine threshold at today's Camarinal Sill is thought to have been incised by at least $200 \mathrm{~m}$ during 

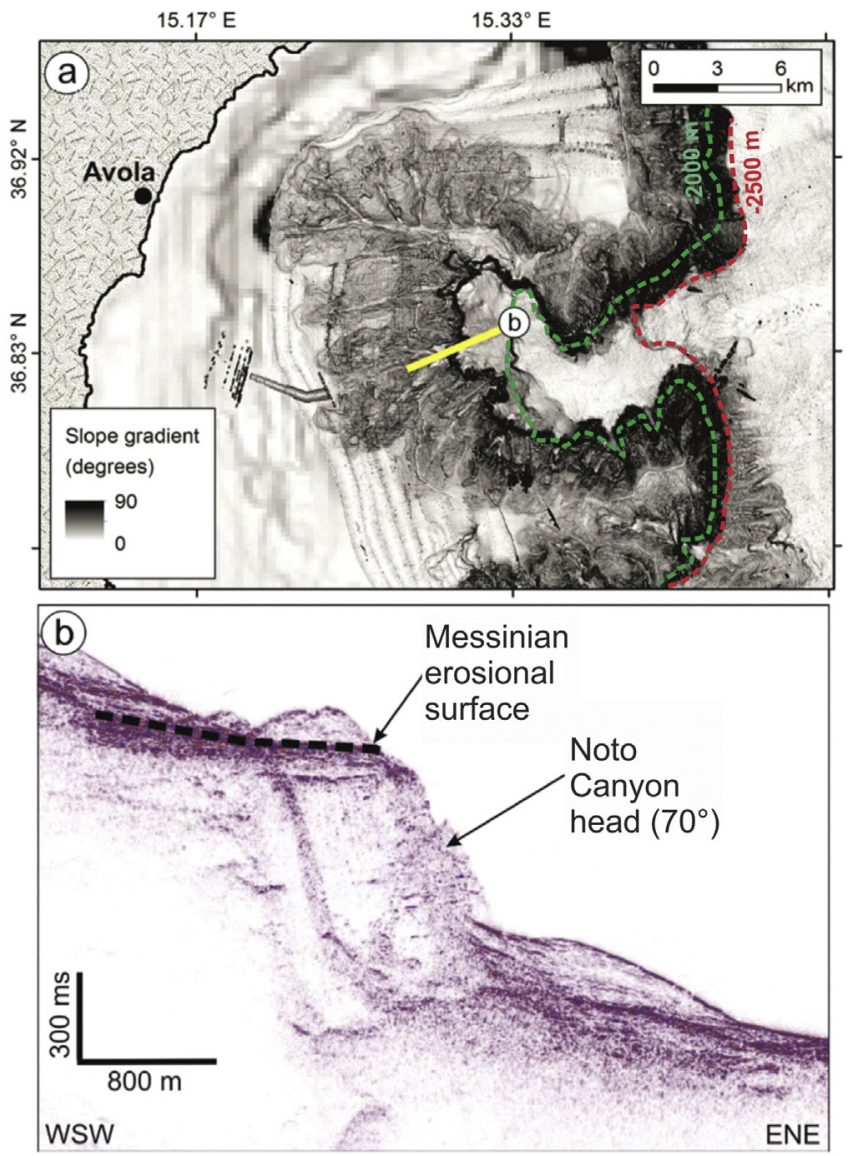

Fig. 4. Possible gateway for the Zanclean flood into the eastern Mediterranean. (a) Map of south-eastern Sicily showing a seafloor slope gradient map of the Noto Canyon. Isobaths denoted by dotted lines. Location in Fig. 1. (b) Seismic reflection profile CIR-07 showing the Noto Canyon head and the Messinian erosional surface upslope. Location in (a). The sediment resting on the acoustic basement in the ENE (bottom of the canyon) is up to $200 \mathrm{~m}$ thick. Modified from Micallef et al. (2018). the flood (Garcia-Castellanos et al., 2009). This number is key in constraining the peak velocity and discharge of the Zanclean flood (Fig. 6; Garcia-Castellanos et al., 2009; Periáñez et al., 2019). To show this, we calculate the feedback between the flow of water (calculated using Manning's equation) and the enlargement of the inlet by erosion (assumed proportional to basal shear stress). using the same algorithm as Garcia-Castellanos et al. (2009). We show two simulations of the Mediterranean refill using two values of sill rock erodability (Fig. 6). Although erodability $k_{e}$ is a still a poorly understood property of rocks and its quantification is limited by orders of magnitude of uncertainty (Garcia-Castellanos and O'Connor, 2018), the erodability value used for our reference model is constrained by the total incision of the flood, estimated at $>200 \mathrm{~m}$ in the present Camarinal Sill (Esteras et al., 2000), The results show that this depth of erosion is reached only if $k_{e}>210^{-4} \mathrm{~m} \mathrm{yr}^{-1} \mathrm{~Pa}^{-1.5}$, which in turn implies a peak water discharge close to $100 \mathrm{~Sv}$ ( 1 Sverdrup $=10^{6} \mathrm{~m}^{3} \mathrm{~s}^{-1}$ ). Smaller values of erodability fail to reproduce the observed depth of the erosional trough across Camarinal and the Strait of Gibraltar.

Nevertheless, the fate of these eroded materials has remained unknown, despite the fact that their present location might be an independent source of evidence to validate the megaflood hypothesis. A first attempt to predict the distribution of these flood deposits has been recently performed (Periáñez et al., 2019) using a Lagrangian 2D hydrodynamic model to simulate the transport of material eroded from the Strait of Gibraltar. The transport of rock particles of variable size, either in suspension or as bed load is calculated using standard sediment transport equations. Water circulation during the flood has been estimated from a hydrodynamic model of the whole Mediterranean Sea (Abril and Periáñez, 2016) based on the assumption that the inlet was enlarged by the flow itself (Garcia-Castellanos et al., 2009). The hydrodynamic model solves the 2D depth-averaged fluid dynamic equations incorporating wetting/drying processes. The model finds the topographic lows in the exposed seafloor along which water flows (Periáñez and Abril, 2015). The numerical solution of the equations yield values for the water velocity over the model domain and modifies water depth preserving the volume of water. Sea-bed stresses over the domain due to the water current are calculated for the suspended sediment transport. The incision model used for calculating the enlargement of the Gibraltar inlet is based on an energy balance for the energy dissipated by the stream of water (when gravitational potential energy decreases) and the energy required for eroding the unit volume of substrate. This explains the erosion of the former Gibraltar isthmus and
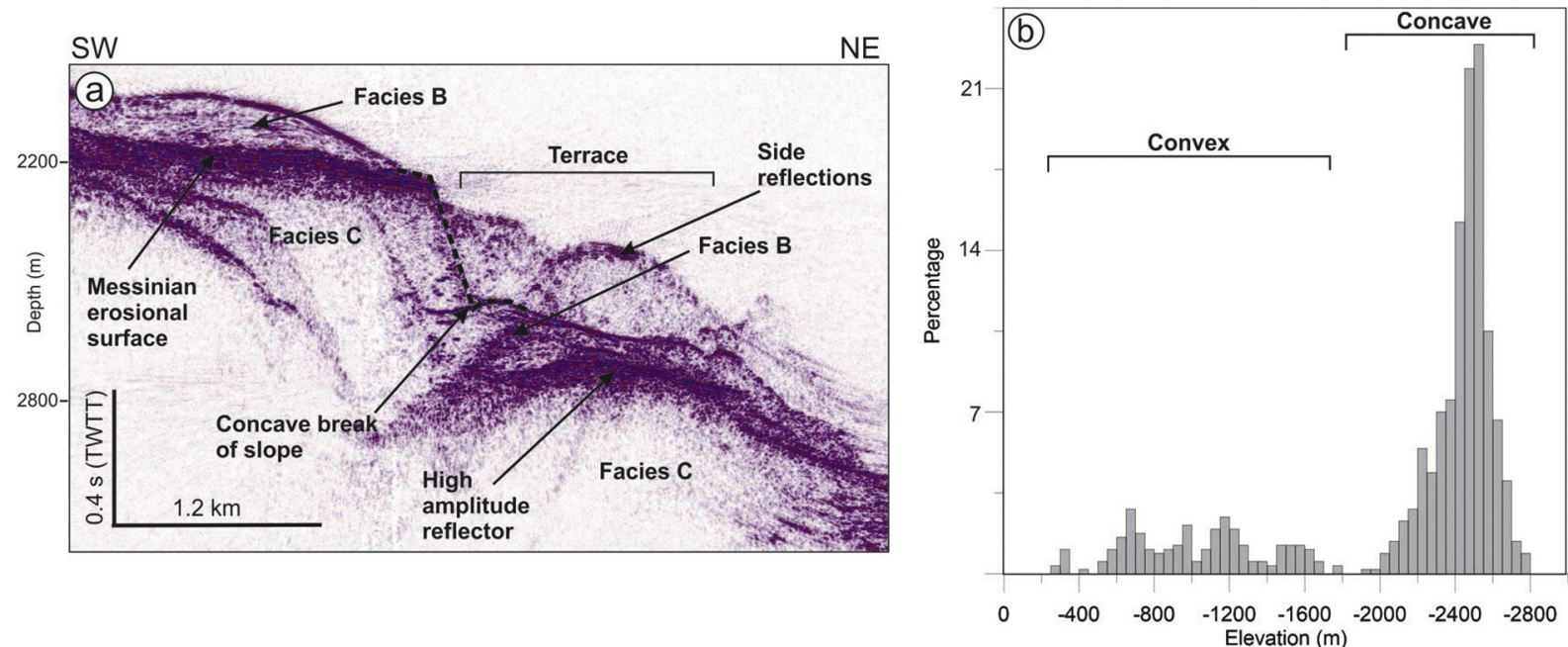

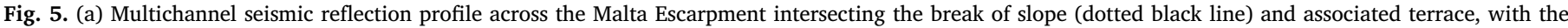

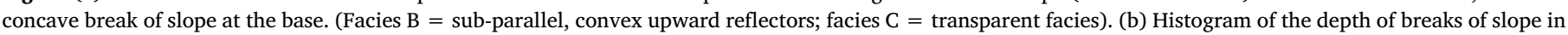

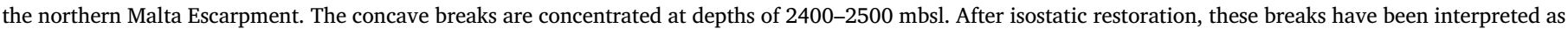

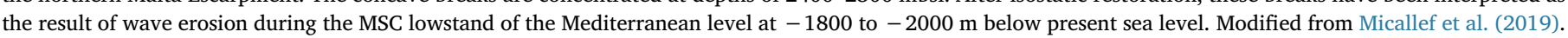


(0)
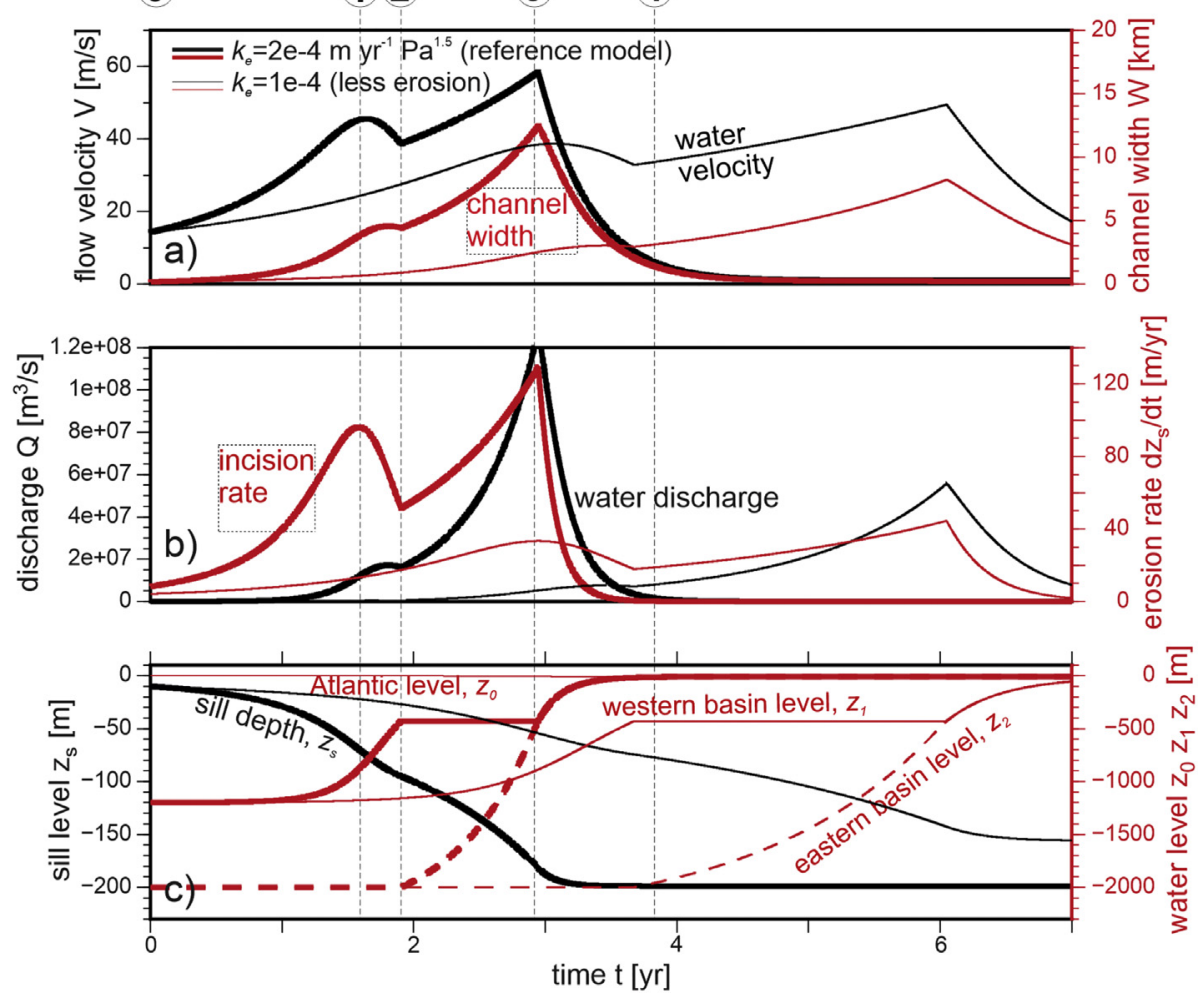

Fig. 6. Modeling results of the evolution of the Zanclean flood based on the same methodology as in Garcia-Castellanos et al. (2009). These two simulations assume different rock erodability $k_{e}$ for the Gibraltar Sill. The refill of the Mediterranean starts with a $10 \mathrm{~m}$ deep inflow river of oceanic water. The reference model (bold lines) erodes this sill down to $-200 \mathrm{~m}$ below the global sea level, whereas imposing half the erodability (thin lines) leads to a sill eroded by only $155 \mathrm{~m}$, less than observed in geophysical data. a) Water velocity and inflow channel width at the Strait of Gibraltar. b) Water discharge and incision rate. c) Inlet depth (black lines) and level of the Atlantic, the Western Mediterranean, and Eastern Mediterranean (red lines). The Sicily Sill is flooded after $1.9 \mathrm{yr}$ in the reference model (3.6 $\mathrm{yr}$ in the less erodible model). Most of the water flow is concentrated within less than two years in the reference model, implying sea level rise rates of up to $10 \mathrm{~m} /$ day in the Mediterranean. Circled numbers and vertical dashed lines show the five stages defined in Fig. 1 (for the reference model only). (For interpretation of the references to colour in this figure legend, the reader is referred to the web version of this article.) the Zanclean Channel (both the branch running through the Alborán Sea and the recessive incision channel extending to the Camarinal Sill in the Gulf of Cádiz). The approach uses as initial conditions the water level drop inferred from the Messinian shoreline reported by Urgeles et al. (2011), ca. $1200 \mathrm{~m}$, and adopts the present-day bathymetry of the Mediterranean as a proxy for the Messinian hypsometry. Sediment transport is described in a Lagrangian framework both for suspended load and bed load. The transport model for suspended load includes the processes of advection (transport with the water current), diffusion (mixing due to water turbulence), and settling of particles. Settling velocity depends on the particle size. Particles are deposited once they reach the bottom if the bed stress is lower than a critical deposition stress. This critical stress depends on the particle size as well. A detailed description of the model and its parameters (particle sizes, settling velocities, critical stresses) may be seen in Periáñez et al. (2019). Bed load transport occurs when a critical velocity is exceeded that depends on the local water depth and sediment size following (Bilgili et al., 2003). Particles are assumed to travel at one-sixth of the depth averaged current (Periáñez et al., 2019).

We show the areas of preferential sediment deposition in the Mediterranean Sea depending on grain size (Fig. 7) for sediments eroded from the Strait of Gibraltar and precisely at the stage of peak discharge, when the sea level has risen to $-170 \mathrm{~m}$. Suspended load is deposited in areas sheltered from the jet of incoming water by the local topography, areas where water current abruptly decreases due to a sudden increase in water depth, and the central zone of eddies, where water current magnitudes also decrease, as well as in areas were the flow changes from more to less restricted. Thus, main deposits are predicted at both sides of the Strait of Gibraltar (i.e., both sides of the Zanclean channel), the Alborán Sea central area and its northern and southern shores during the peak discharge. Once a particle leaves the Alborán Sea, it follows two main routes, one along the African coast and the second south of the Balearic Islands and Sardinia. Particles, as they are transported with the water jet, fall according to their settling velocity and finally they are deposited on the seabed in areas of lower flow energy. The distance of these deposits to the Strait of Gibraltar increases as particle size decreases. As a consequence, very extensive deposits of mainly silt and fine sand are predicted between the Balearic Islands and Sardinia due to energy loss and deposition along a northern current jet (Fig. 7c-e). Only a small fraction of sediment, particularly the finer particles, reaches the eastern Mediterranean through the Sicily Sill. Long deposits may also be seen along the Algerian coast, tracing the route of the stronger southern jet (Fig. 7a).

In contrast, sediment particles transported as bed load are deposited following the main streamlines. Deposits of very coarse sediment eroded from the Strait of Gibraltar and transported as bed load are more localized in space than sediment transported in suspension (Fig. 7b; Periáñez et al., 2019). In interpreting these model results, one must bear in mind that they are valid for the adopted bathymetry, which we take as the present one due to the absence of reconstructions of the Messinian paleo-bathymetry. Therefore, the relevance for the Zanclean flood is in the qualitative relationships between flow and deposition, rather than the exact location predicted for the deposits, particularly in areas of significant tectonic deformation such as the Tyrrhenian and the Alborán seas.

\subsection{Identification of possible flood deposits in seismic reflection and borehole data}

While the volume of eroded bedrock and sediment in Gibraltar and Alborán was estimated at $500 \mathrm{~km}^{3}$ (Garcia-Castellanos et al., 2009), more recent data in Figs. 2 and 8 suggest this volume could be double that amount, since the erosional trough is now known to extend towards the east until the Algerian basin (Fig. 8). $1000 \mathrm{~km}^{3}$ of sediment evenly distributed over the extent of the western Mediterranean evaporites $\left(410^{5} \mathrm{~km}^{2}\right.$ ) would imply a sediment layer of only $2 \mathrm{~m}$, undetectable in the available seismic stratigraphy. However, our model predictions suggest a strong localization of the flood deposits in areas of low energy (Fig. 7), and therefore larger size deposits are expected to be detectable in the seismic record and apparent in the core sedimentary 


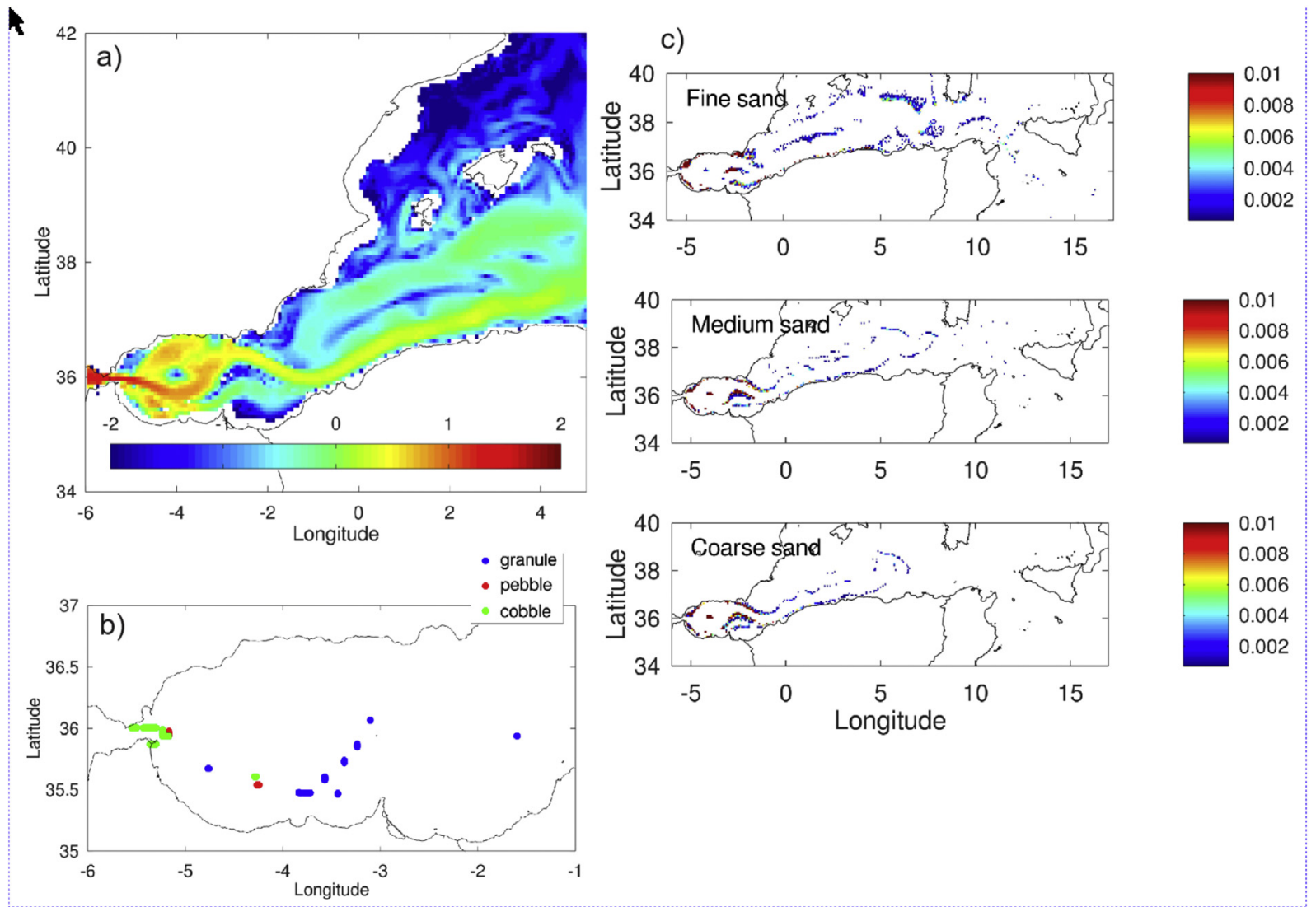

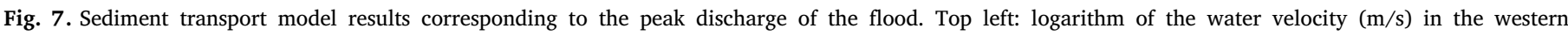

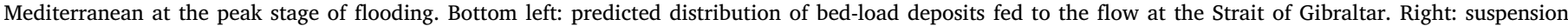

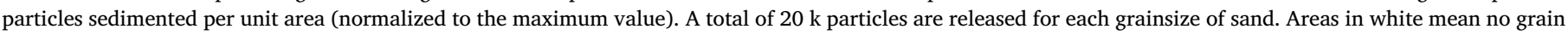

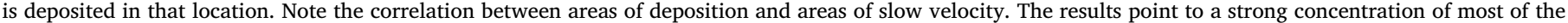
deposits in $<1 \%$ of the area of the Western Mediterranean. Modified from Periáñez et al. (2019).

record from drilling. Here we report new and recently published possible Zanclean flood deposits within the eastern Alborán Basin and off the Malta Escarpment based on seismic reflection profiles.

\subsection{Possible megabar deposits in the Alborán Sea}

Seismic reflection profiles show the presence of an elongated sedimentary body (Fig. 8C to D) associated to the erosion channel shown in Figs. 2 and 3. These deposits have contrasting seismic character with the underlying Miocene and overlying Pliocene deposits. Seismically they are characterized by chaotic, hyperbolic and discontinuous stratified facies. They form an elongated body up to $163 \mathrm{~m}$ thick, $35 \mathrm{~km}$ long and $7 \mathrm{~km}$ wide, located next to the main erosion channel and oriented parallel to its main trend (Fig. 8A). The Upper Miocene and Plio-Quaternary seismic stratigraphy of the Alborán Sea (Estrada et al., 2011; Juan et al., 2016), based on correlation with commercial, DSDP and ODP sites, indicate that this body is sandwiched between the MSC erosive surface (MES) and the Pliocene contourites deposited once the oceanic circulation was restored. The presence of these deposits occurs in the eastern Alborán basin, behind (in the lee side of) a pre-MSC volcanic edifice.

Their elongated plan-view shape, seismic facies, stratigraphic position and their orientation parallel to the flooding channel, are compatible with megabar flood deposits described for Pleistocene outburst flood scenarios such as the Altay floods (Carling et al., 2009; Herget, 2005). We propose that these deposits are related to the formation to the Zanclean erosion channel and represent possible megaflood deposits that were deposited because of the presence of a volcanic obstacle. This edifice may have acted as a topographic obstacle to the impinging flood flow, allowing the accumulation of sediments near the peak of the Zanclean flood, in the protected area at the lee side of the volcano. Similar sedimentary bars of larger grain size (boulder) have also been reported downstream the Snake River, spillway of the Bonneville flood in the Late Pleistocene (O'Connor, 1993), in areas where the flooding waters decreased in flow energy, for instance as a result of entering a less restricted topography.

Chaotic deposits have been reported as filling the bottom of the erosion channel in a seismic profile a few kilometers to the west of the section shown in Fig. 7b (Periáñez et al., 2019), and interpreted as the deposition of flood-erosion products during the late stages of the flood. These are not visible in the Conrad 823 seismic line, perhaps due to the smaller thickness that is undetectable in the seismic record, which in turn was the result of a more constrained flow imposed by the seamounts in this area. However, it must be noted that ODP site 977 (Figs. 1 and 7) drilled the lowermost part of the southern and northern erosion channels, respectively, reaching partially cemented rounded gravels and sands that contained a mixed fauna of Miocene and Pliocene, interpreted as possibly related to the Zanclean reflooding (Comas et al., 1996). ODP site 978 also reported pebble-sized clasts in the equivalent stratigraphic position. Model results in Fig. $7 \mathrm{~b}$ predict that gravel-to-pebble-sized clasts can be dragged for a few hundreds of $\mathrm{km}$ at peak discharge, thus suggesting that the pebbles recovered from the drilling cores could come from the numerous volcanic sea mounts located further to the west, in the center of the Alborán Basin.

\subsection{Possible megaflood deposits in the Ionian Sea}

Multichannel seismic reflection data in the western Ionian Basin 



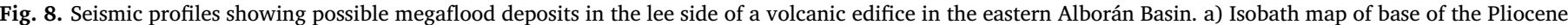

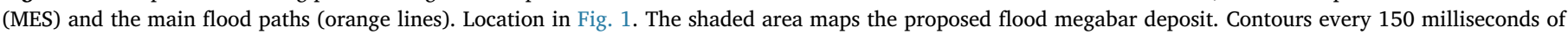

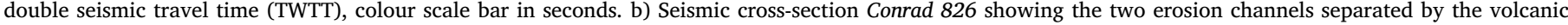

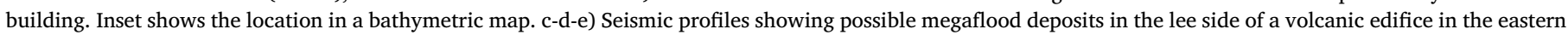

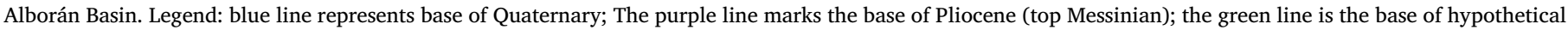

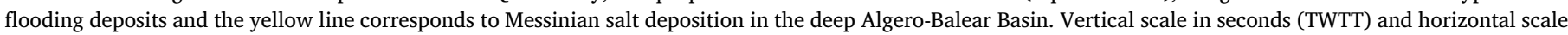
in meters. (For interpretation of the references to colour in this figure legend, the reader is referred to the web version of this article.)

exhibit an acoustically chaotic to transparent body of up to $860 \mathrm{~m}$ in thickness and $1430-1620 \mathrm{~km}^{3}$ in volume, covering an area of $11,000 \mathrm{~km}^{2}$ buried at depth between 3.4 and $4.8 \mathrm{~km}$ below sea level (Fig. 9; (Micallef et al., 2018)). Towards the west, this body terminates abruptly against the Malta Escarpment. Although this unit has not been drilled, its stratigraphic position is placed with confidence between the Messinian Upper Unit (UU) and the overlying 200-400 m thick PlioPleistocene sediment layer characterized by well-laminated, continuous reflectors. Therefore, its age is at or near the Miocene/Pliocene boundary (5.33 Ma).

The scale of this feature cannot be readily explained by collapse of the eastern margin of the Malta Escarpment. A large submarine mass movement has been discarded as a possible explanation for the origin of Unit 2 due to the lack of nearby scars of sufficient volume and the hard (limestone) lithology of the escarpment (Micallef et al., 2018). A formation by folded Messinian upper gypsum is also discarded based on the seismic velocities measured $(2.3-2.6 \mathrm{~km} / \mathrm{s})$, which are significantly lower than the $3.1 \mathrm{~km} / \mathrm{s}$ associated with gypsum deposits. Finally, the lack of local sources of sediment (the canyons along the Malta Escarpment combined add up to only $1100 \mathrm{~km}^{3}$ in volume), suggests that this unit may be a megaflood deposit. The seismic texture and the isopachs of the body indicate that this sedimentary unit represents highenergy deposits sourced in the W, beyond the Malta Escarpment. Its location next to the Noto amphitheater-shaped canyon (SE Sicily margin; Fig. 9) suggests a NW provenance of the flow, likely through the Pelagian Platform. Thus, the interpretation by Micallef et al. (2018) is that the chaotic body records deposition from a megaflood flow as the water refill of the western Mediterranean overtopped the Sicily Sill.
These overtopping waters would plunge into the partially desiccated eastern Mediterranean basin, possibly at a level of -1750 to $-1900 \mathrm{~m}$ as suggested by the wave erosion marks preserved in the escarpment, the base of the Noto Canyon, and the base of the flood deposits (Figs. 4, 5 \& 9).

\section{Discussion}

\subsection{Significance for the Messinian salinity crisis}

The Zanclean flood hypothesis is closely entangled to the controversy about the desiccation of the Mediterranean Sea during the Messinian salinity crisis. The occurrence and extent of this desiccation by the end of the Neogene is far from a consensus among the scientific community (e.g., Roveri et al., 2014a). The main evidence questioning a kilometric-scale drawdown right before the Pliocene is the ubiquitous presence of Lago-Mare facies (fresh to brackish water fauna that also include marine fish; Carnevale et al., 2017) during the last stage of the MSC, at elevations close to normal sea level (Orszag-Sperber, 2006). The Lago-Mare is characterized by mollusks, ostracods and/or dinoflagellate cysts of Paratethyan-type (originating from the Black Sea region) indicating a brackish sedimentary environment before the return to normal open-marine environment across the Miocene-Pliocene boundary. The widespread presence of these sediments from southern Spain to the Levant Basin suggests that, right before the Pliocene, the Mediterranean was a single connected body of water with its level above the Sicily Sill (today at $-430 \mathrm{~m}$ ) and that its salinity was lower than the open ocean. To explain the abrupt end of the MSC without a 

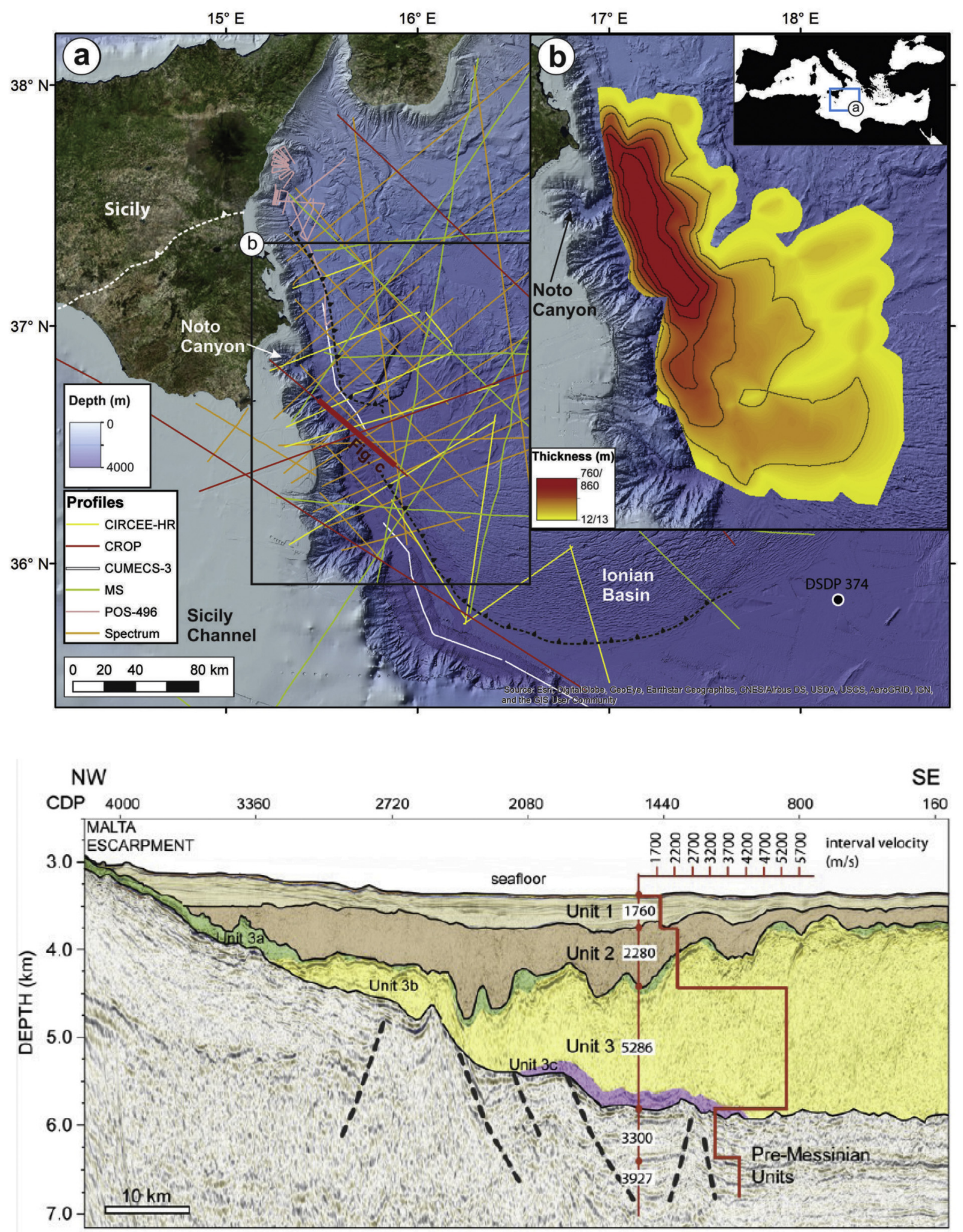

Fig. 9. a) and b) lateral extension of the transparent unit interpreted as megaflood deposits off the Malta escarpment, next to the Noto canyon. c) Seismic stratigraphy of western Ionian Basin. Interpreted units on reflection profile CROP 21 (pre-stack depth-migrated). The red plot shows the estimated PSDM seismic velocity profile. Correlation with DSDP drilling site 374 indicates that Unit 1 corresponds to Pliocene-Quaternary pelagics, contourites and turbidites; Unit 3 correlates with MSC evaporites including a highly reflective and mostly deformed upper unit made of gypsum and marls (3a, green), and a typically reflector-less unit with a basin-fill geometry made of halite and also known as mobile unit (3b, yellow); a lower, highly reflective, discontinuous unit (3c, purple) has never been drilled yet but is attributed to lower gypsum or clastics. Modified from (Micallef et al., 2018). (For interpretation of the references to colour in this figure legend, the reader is referred to the web version of this article.) 
significant drawdown that can trigger a flood, Marzocchi et al. (2016) proposed a Mediterranean-wide hydrological pump model driven by the strong salinity contrast between the Mediterranean, the Atlantic, and the Paratethys. This can explain the co-existence of dense Atlantic water influx from Gibraltar and lighter brackish water influx from the Paratethys during the Lago-Mare stage prior to the end of the MSC, all under normal sea-level conditions. Supporting this view, the ages of the Neogene marine seaways onshore the Alborán Sea suggest that the Gibraltar Strait (Krijgsman et al., 2018) may have never been fully closed (Manzi et al., 2005), questioning the idea of a completely isolated Mediterranean Sea during the MSC. In order to keep a kilometric drawdown for a period longer than a few thousands of years, a full disconnection of the marine gateways is required (Garcia-Castellanos and Villaseñor, 2011), because otherwise the inflow of water would trigger a fast erosion and reestablish the level of the Mediterranean Sea. Finally, models excluding a significant sea level drawdown explain the erosion features of the Mediterranean margins as the result of hyperpycnal density currents related to storage of high-density water due to evaporation during the MSC (Roveri et al., 2014b). A possible explanation for the intriguing Lago-Mare facies is that it post-dates the flooding. Based on outcrops near Málaga (southern Spain), Do Couto et al. (2014) suggest that the Lago-Mare sediments were deposited after the Atlantic flooding, which would then have taken place at 5.46 Ma instead of the Messinian/Zanclean boundary (5.33 Ma).

To add to these conflicting observations, recent industrial seismicreflection data-sets in the deep Ionian Sea (Sirt Basin, Libya) and in the deep Levant Basin (offshore Syria) show the existence of large fluvial sedimentary systems formed after the halite precipitation (Bowman, 2012; Madof et al., 2019). In the Levant, these fluvial systems are longer than $100 \mathrm{~km}$ and interpreted as fluvio-deltaic lobes resting directly atop the Messinian halite and seem coeval with the erosion of deformed salt layers (Bowman, 2012; Kartveit et al., 2019; Madof et al., 2019). These are interpreted as the result of vast paleo-river basins draining areas of Africa and the Middle East region during the lowering of the Mediterranean Sea level. In contrast, seismic stratigraphy in the same area suggests that salt promontories formed by salt flow in the sea floor were truncated by dissolution under a deep, stratified water column, conflicting with the possibility of a seafloor exposure (Gvirtzman et al., 2017). In the absence of drill holes and age determinations, the presumed fluvial lobes are ambiguously correlated to the Lago-Mare phase, but could they alternatively predate it and predate the megaflood? The seismic stratigraphic record to date fails to answer this question so far and points to the need for scientific drilling.

The evidence shown in this chapter supports an abrupt, catastrophic refill of the Mediterranean in the form of an outburst flood caused by the overtopping of the Atlantic through a Neogene isthmus in Gibraltar (Garcia-Castellanos et al., 2009). The same mechanism has been described for tens of Pleistocene overtopping lakes that triggered outburst floods (Garcia-Castellanos and O'Connor, 2018). Such scenario requires a significantly low level in the Mediterranean Sea (hundreds of meters at least) prior to flooding, to be consistent with the erosion and flood deposits reported in the Alborán area and the Malta Escarpment. But it does not require a complete desiccation of neither of the Mediterranean sub basins.

\subsection{Comparison to other megafloods}

The Missoula floods in the Scablands region (Washington, USA) are the first studied and best-known outburst floods that have. Based on information as diverse as the elevation of ice-rafted boulders, megaripple marks, the size of mobilized blocks and OD step-backwater and 3D hydrodynamic modeling, several tens of events of up to around $10^{7}$ $\mathrm{m}^{3} \mathrm{~s}^{-1}$ in discharge (O'Connor and Baker, 1992; Benito and O'Connor, 2003; Alho et al., 2010; Larsen and Lamb, 2016) have been described in this region dating between 18.5 and 15 thousand years ago (late Pleistocene). Erosional and deposition features, including km-scale regressive erosion cliffs as the Dry Falls or the Potholes Coulee are attributed to a series of outburst events involving a water flow deeper than $100 \mathrm{~m}$ at speeds up to $15 \mathrm{~m} / \mathrm{s}$. Such horseshoe- or amphitheatershaped cliffs, frequent smoking guns for megaflooding, are similar to the Noto Canyon in the Malta Escarpment (Fig. 4). Such features are found widespread across the state of Washington and attributed to the Missoula floods. The Pothole coulee is ca. $2 \mathrm{~km}$ wide and therefore narrower than the Noto Canyon $(6 \mathrm{~km})$, a priori consistent with the 10 times higher peak discharge derived for the Zanclean flood (GarciaCastellanos et al., 2009; Abril and Periáñez, 2016). Similar amphitheater-headed valleys have been linked to megaflooding events in Idaho (Lamb et al., 2008). Because of the current impossibility to date the formation of the Noto Canyon, the only indication linking its origin to the Zanclean flood is its morphology, its location next to the possible megaflood deposits in Fig. 9, and the absence of other explanations for its formation (Micallef et al., 2018).

The Altay flood along the Katun River (Altay Republic, Russia) is another case scenario where discharge rates comparable to the Missoula Floods ( $\sim 10 \mathrm{~Sv}$ ) have been estimated. Here, outburst-flood sedimentary features along mountain valleys are well exposed due to tributaries of the main flooding channel that were backflooded during the events. An abundant depositional feature is megabars, equivalent to fluvial bars but two orders of magnitude larger and thought to form near the time of peak discharge of outburst floods. The concept in Fig. 10 is based on a gravel megabar exposure cut by a tributary river after the flooding. It shows three cycles of flood deposition separated by slack water deposits, interpreted as an indication for repeated flooding. Accretion results from intense fallout of suspended gravels and is then rearranged by unsteady traction transport during upper stage surges. As the flood discharge wanes, cross-beds may form due ripple and dune migration during the lower stage (Carling et al., 2009). In the analogue case of the Zanclean flood, one single flooding event is envisaged. If, as proposed, the sedimentary feature shown in Fig. 8 corresponds to an equivalent megabar formed during the transition from high to low energy flow in the Alborán Sea, then an upward-fining sequence of mostly suspended sediment would be expected within that unit. However, the potential megabar shown in Fig. 8 has not been drilled so far, and the existing seismic surveys do not have enough resolution to detect grain-size changes or features like those in Fig. 10. Therefore, while we are unable to further check the consistency between the unit identified in Alborán Sea and the megabars in the Altay, the morphological distribution of the sediments (elongated, parallel and next to the main channel) make it an important candidate site for future drilling to find supporting lithological evidence for the Zanclean flood deposits.

\subsection{Future search for further evidence}

A fundamental peculiarity of the Zanclean flood setting relative to Pleistocene outburst floods is that, whereas its water source (the global ocean) is virtually infinite in volume, the sink (the desiccated Mediterranean Sea) is not. During the flood, the western shoreline of the western Mediterranean should raise and shift towards the Strait of Gibraltar, possibly hindering the spatial concentration of deposits. Nevertheless, because of the large size of the Mediterranean basin, the ever-increasing flooding discharge becomes significant to the water budget only when the flood discharge becomes comparable to hydrological deficit (presently 75,000 $\mathrm{m}^{3} \mathrm{~s}^{-1}$ ). Therefore, future geophysical exploration of the western margin of the Algerian basin should address the presence of buried Zanclean flood deposits postulated by the hydrodynamic models.

The numerical modeling results in Fig. 7 provide an explanation for the $15 \mathrm{~cm} \mathrm{M/P} \mathrm{transition} \mathrm{found} \mathrm{in} \mathrm{ODP} \mathrm{site} 974$ in the Tyrrhenian Sea (Fig. 1 for location) (Iaccarino and Bossio, 1999; Pierre et al., 2006) and the $2-3 \mathrm{~cm}$ of $>0.3 \mathrm{~mm}$ of terrigenous clasts (medium sand) recovered just above the M/P boundary in site 975 at the South Balearic Basin (Iaccarino and Bossio, 1999; Zahn et al., 1999) consisting of 


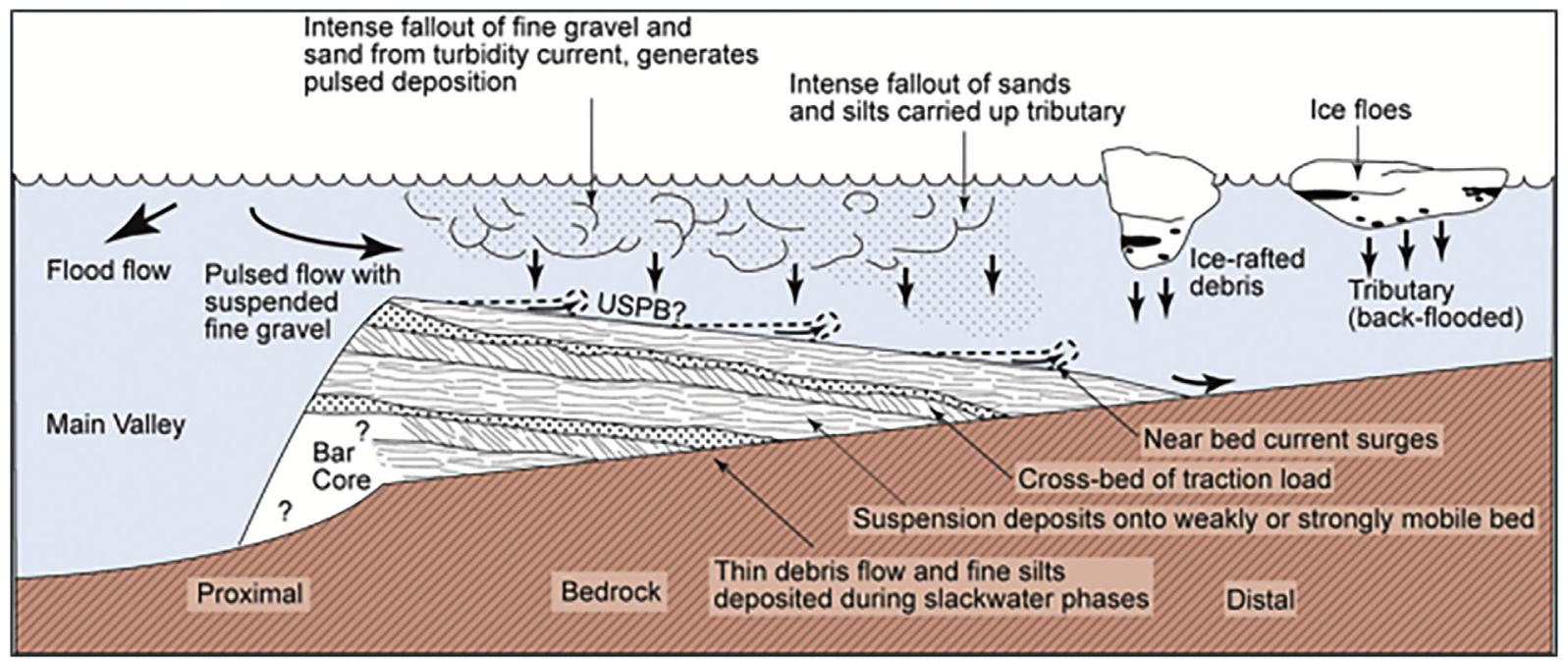

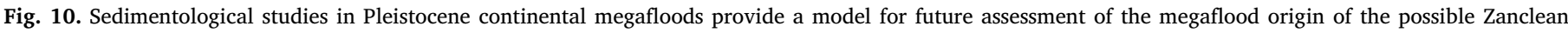

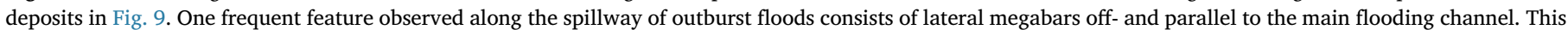

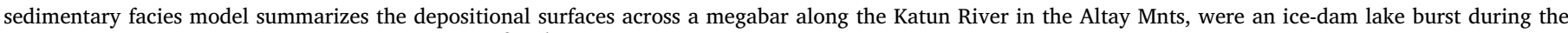

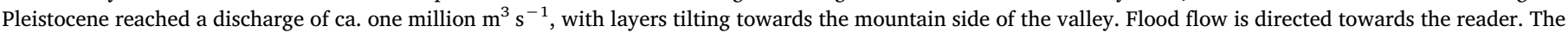

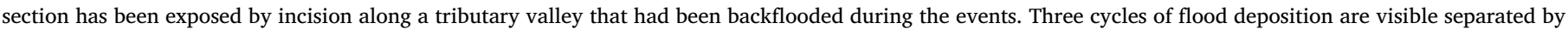

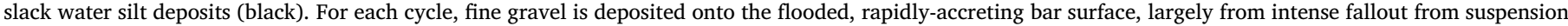

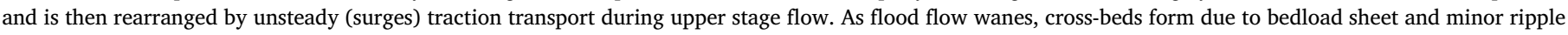

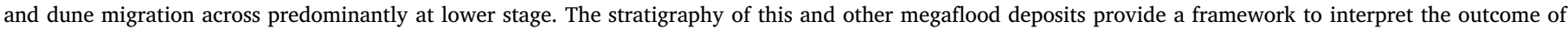
future scientific drilling of the much older and buried Zanclean flood deposits. Modified from Carling et al. (2009).

"foraminifera and calcareous nannofossils that are reworked from the early marine Messinian, while the ostracod fauna reflects the original paleoenvironment". The inflow of Atlantic waters at unprecedented discharge rates close to $10^{8} \mathrm{~m}^{3} \mathrm{~s}^{-1}(100 \mathrm{~Sv})$ are proven capable of transporting medium sand and foraminifera at such distances (Fig. 7). In using these models for searching flood erosional and depositional features in the Alborán sea, one must consider the uncertainty induced by the use of today's bathymetry as a proxy for the paleogeography of the region. During the Messinian, most of the Tyrrhenian Sea, for instance, was still not formed by the retreat of the Calabrian Arc. In the Alboran Sea, the paleo bathymetry at the time of flooding may have been significantly different from today, since the lithosphere was younger, thinner, hotter and therefore more buoyant (Booth-Rea et al., 2018), and the compressional tectonics of the ongoing convergence between Africa and Eurasia has raised most of the Alborán Ridge during the Plioquaternary. Since the Messinian, Africa has approached Eurasia by 20 to $100 \mathrm{~km}$ (in the west and the east of the Mediterranean Sea, respectively), and the bathymetry has been modified by a layer of PlioQuaternary deposits of, typically, a few hundreds of meters. The lack of good reconstructions of the bathymetric and geographic changes of the Mediterranean Sea at the time of the flooding limits a more detailed prediction of the locations ideal for future megaflood deposits exploration.

The present review shows recent independent assessments of the Zanclean megaflood hypothesis, and highlights the need for further future research in order to test it. Seismic studies may validate it if clinoform deposits and found in the westernmost Algerian basin and dated to the end of the MSC, for example. But a more direct test may arrive from drilling the sedimentary deposits described in the Alborán basin and in the Ionian Sea. In this regard, the outcome of three drilling proposals (DEMISE, DREAM, and IMMAGE) that are currently undergoing a second round of review by IODP, will be crucial. If approved and drilled, they have the potential to decipher many of the aforementioned open scientific questions regarding the end of the Messinian salinity crisis.

\section{Conclusions}

We have summarized a set of observations that provide additional evidence to the previously identified erosional channel at the Strait of Gibraltar, supporting a megaflood of the Mediterranean basin near the limit between the Miocene and the Pliocene. Based on them, we can draw the following conclusions:

1. If the $>200 \mathrm{~m}$ erosion at the Strait of Gibraltar was caused by the refilling of the Mediterranean Sea, numerical modeling shows that this erosion implies a flood of an unprecedented discharge, possibly above $100 \mathrm{~Sv}\left(10^{8} \mathrm{~m}^{3} \mathrm{~s}^{-1}\right)$.

2. The amphitheater-headed Noto Canyon, off SE Sicily, is compatible with an overspill the Zanclean flood from the western to the eastern Mediterranean across the Sicily sill. The morphology of the canyon and the Malta Escarpment slope suggest a Mediterranean Sea level at the time of the flood -1750 to $-1900 \mathrm{~m}$ lower than today.

3. A $1600 \mathrm{~km}^{3}$ sedimentary body to the east of the Noto Canyon, laying atop the Messinian salt layer and below the Plio-Quaternary muds is compatible with a megaflood deposit delivered to the eastern basin and bringuing to an end the drawdown phase.

4. A $163 \mathrm{~m}$ thick, elongated sediment body of $35 \times 7 \mathrm{~km}$, oriented parallel to the main flood channel in the Alborán Sea and located in the lee side of a seamount, is compatible with megabars formed along the largest documented continental outburst floods.

\section{Declaration of Competing Interest}

None.

\section{Acknowledgements}

Funding has been provided by the COST Action Medsalt CA15103, by the ETN SaltGiant (European Union funded, Horizon2020, Marie Skłodowska-Curie grant agreement No 765256 and 674899) and by the Spanish public projects MITE (CGL2014-59516) FAUCES (CMT201565461-C2-R, MINECO/FEDER) and DAMAGE (AEI/FEDER CGL2016- 
80687-R).

\section{References}

Abril, J.M., Periáñez, R., 2016. Revisiting the time scale and size of the Zanclean flood of the Mediterranean (5.33Ma) from CFD simulations. Mar. Geol. 382, 242-256. https://doi.org/10.1016/j.margeo.2016.10.008.

Alho, P., Baker, V.R., Smith, L.N., 2010. Paleohydraulic reconstruction of the largest Glacial Lake Missoula draining(s). Quat. Sci. Rev. 29, 3067-3078. https://doi.org/10. 1016/j.quascirev.2010.07.015.

Bache, F., Olivet, J.L., Gorini, C., Rabineau, M., Baztan, J., Aslanian, D., Suc, J.P., 2009. Messinian erosional and salinity crises: view from the Provence Basin (Gulf of Lions, Western Mediterranean). Earth Planet. Sci. Lett. 286, 139-157.

Bache, F., Gargani, J., Suc, J.-P., Gorini, C., Rabineau, M., Popescu, S.-M., Leroux, E., Couto, D.D., Jouannic, G., Rubino, J.-L., Olivet, J.-L., Clauzon, G., Dos Reis, A.T., Aslanian, D., 2015. Messinian evaporite deposition during sea level rise in the Gulf of Lions (Western Mediterranean). Mar. Pet. Geol. 66, 262-277. https://doi.org/10. 1016/j.marpetgeo.2014.12.013.

Benito, G., O'Connor, J.E., 2003. Number and size of last-glacial Missoula floods in the Columbia River valley between the Pasco Basin, Washington, and Portland. Oregon. Geol. Soc. Am. Bull. 115, 624-638. https://doi.org/10.1130/0016-7606(2003) $115<0624$ :NASOLM $>2.0$. CO;2.

Bilgili, A., Swift, M.R., Lynch, D.R., Ip, J.T.C., 2003. Modeling bed-load transport of coarse sediments in the Great Bay Estuary, New Hampshire. Estuar. Coast. Shelf Sci. 58, 937-950. https://doi.org/10.1016/j.ecss.2003.07.007.

Blanc, P., 2000. Of sills and straits: a quantitative assessment of the messinian salinity crisis. Deep Sea Res. Part Oceanogr. Res. Pap. 47, 1429-1460. https://doi.org/10. 1016/S0967-0637(99)00113-2.

Blanc, P.L., 2002. The opening of the Plio-Quaternary Gibraltar Strait: assessing the size of a cataclysm. Geodin. Acta 15, 303-317.

Blanc, P.L., 2006. Improved modelling of the Messinian Salinity Crisis and conceptual implications. Palaeogeogr. Palaeoclimatol. Palaeoecol. 238, 349-372.

Booth-Rea, G., Ranero, R., Grevemeyer, I.C., 2018. The Alboran volcanic-arc modulated the Messinian faunal exchange and salinity crisis. Sci. Rep. 8. https://doi.org/10 1038/s41598-018-31307-7.

Bowman, S.A., 2012. A comprehensive review of the MSC facies and their origins in the offshore Sirt Basin, Libya. Pet. Geosci. 18, 457-469. https://doi.org/10.1144/ petgeo2011-070.

Breda, A., Mellere, D., Massari, F., Asioli, A., 2009. Vertically stacked Gilbert-type deltas of Ventimiglia (NW Italy): the Pliocene record of an overfilled Messinian incised valley. Sediment. Geol. 219, 58-76. https://doi.org/10.1016/j.sedgeo.2009.04.010.

Bretz, J.H., 1925. The Spokane fl ood beyond the channeled scablands. J. Geol. 33, 97-125.

Campillo, A.C., Maldonado, A., Mauffret, A., 1992. Stratigraphic and Tectonic evolution of the Western Alboran Sea late Miocene to recent. Geo-Mar. Lett. 12, 165-172.

Carling, P.A., Martini, I.P., Herget, J., Borodavko, P., Parnachov, S., 2009. Megaflood sedimentary valley fill: Altai Mountains. In: Siberia, in: Megaflooding on Earth and Mars. Cambridge University Press, Cambridge, pp. 243-264. https://doi.org/10. 1017/CBO9780511635632.013.

Carnevale, G., Landini, W., Sarti, G., 2006. Mare versus Lago-mare: marine fishes and the Mediterranean environment at the end of the messinian salinity crisis. J. Geol. Soc. 163, 75-80. https://doi.org/10.1144/0016-764904-158.

Carnevale, G., Pierre, F.D., Natalicchio, M., Landini, W., 2017. Fossil Marine Fishes and the? Lago Mare? Event: has the Mediterranean ever Transformed into a Brackish lake? [WWW Document]. https://doi.org/10.1127/nos/2016/0343.

Clauzon, G., 1978. The Messinian Var canyon (Provence, southern France) Paleogeographic implications. Mar. Geol. 27, 231-246.

Clauzon, G., 1982. Le canyon messinien du RhÃ'ne: une preuve dÃ $@$ cisive du “desiccated deep-basin model” (HsÃ̃1/4, Cita et Ryan, 1973). Bull Soc GÃ@ol Fr 24, 597-610.

Comas, M.C., Zahn, R., Klaus, A., 1996. Comas et al., 1996 ODP 977 Alborán ir161_07.pdf. Proceedings of the Ocean Drilling Program. Initial Reports.

Do Couto, D., Popescu, S.-M., Suc, J.-P., Melinte-Dobrinescu, M.C., Barhoun, N., Gorini, C., Jolivet, L., Poort, J., Jouannic, G., Auxietre, J.-L., 2014. Lago Mare and the Messinian Salinity Crisis: evidence from the Alboran Sea (S. Spain). Mar. Pet. Geol. 52, 57-76. https://doi.org/10.1016/j.marpetgeo.2014.01.018.

Duggen, S., Hoernie, K., Van den Bogaard, P., Rapke, L., Morgan, J.P., 2003. Deep roots of the Messinian salinity crisis. Nature 422, 602-606.

Escutia, C., Maldonado, A., 1992. Paleogeographic implications of the Messinian surface in the Valencia Trough Northwestern Mediterranean Sea. In: Banda, E., Santanach, P. (Eds.), Geology and Geophysics of the Valencia Trough. 203. Tectonophysics, Western Mediterranean, pp. 263-284.

Esteras, M., Izquierdo, J., Sandoval, N.G., Bahmad, A., 2000. Evolución morfológica y estratigráfica plio-cuaternaria del umbral de Camarinal (estrecho de Gibraltar) basada en sondeos marinos. Rev. Soc. GeolÃ ${ }^{3}$ gica EspaÃ \pm a 13, 539-550.

Estrada, F., Ercilla, G., Gorini, C., Alonso, B., VÃ̃zquez, J.T., GarcÃ-a-Castellanos, D. Juan, C., Maldonado, A., Ammar, A., Elabbassi, M., 2011. Impact of pulsed Atlantic water inflow into the Alboran Basin at the time of the Zanclean flooding. Geo-Mar. Lett. 31, 361-376. https://doi.org/10.1007/s00367-011-0249-8.

Estrada, F., Galindo-Zaldívar, J., Vázquez, J.T., Ercilla, G., D’Acremont, E., Alonso, B., Gorini, C., 2018. Tectonic indentation in the central Alboran Sea (westernmost Mediterranean). Terra Nova 30 (1), 24-33. https://doi.org/10.1111/ter.12304.

Garcia-Castellanos, D., O'Connor, J.E., 2018. Outburst floods provide erodability estimates consistent with long-term landscape evolution. Sci. Rep. 8. https://doi.org/10. 1038/s41598-018-28981-y.

Garcia-Castellanos, D., Villaseñor, A., 2011. Messinian salinity crisis regulated by competing tectonics and erosion at the Gibraltar arc. Nature 480, 359-363.

García-Castellanos, D., Estrada, F., JimÃđCnez-Munt, I., Gorini, C., Fernández, M. $\operatorname{Verg} \tilde{A} \odot s$, J., De Vicente, R., 2009. Catastrophic flood of the Mediterranean after the Messinian salinity crisis. Nature 462, 10. December 2009. https://doi.org/10.1038/ nature08555.

García-Veigas, J., Cendón, D.I., Gibert, L., Lowenstein, T.K., Artiaga, D., 2018. Geochemical indicators in Western Mediterranean Messinian evaporites: implications for the salinity crisis. Mar. Geol. 403, 197-214. https://doi.org/10.1016/j.margeo. 2018.06.005.

Gvirtzman, Z., Manzi, V., Calvo, R., Gavrieli, I., Gennari, R., Lugli, S., Reghizzi, M., Roveri, M., 2017. Intra-Messinian truncation surface in the Levant Basin explained by subaqueous dissolution. Geology 45, 915-918. https://doi.org/10.1130/G39113.1.

Haq, B., Gorini, C., Baur, J., Moneron, J., Rubino, J.-L., 2020. Deep Mediterranean's Messinian evaporite giant: how much salt? Glob. Planet. Change 184, 103052. https://doi.org/10.1016/j.gloplacha.2019.103052.

Hardie, L.A., Lowenstein, T.K., 2004. Did the Mediterranean Sea Dry out during the Miocene? A reassessment of the evaporite evidence from DSDP Legs 13 and 42A Cores. J. Sediment. Res. 74, 453-461. https://doi.org/10.1306/112003740453.

Herget, J., 2005. Reconstruction of Pleistocene ice-dammed lake outburst floods in the Altai Mountains, Siberia, special papers. In: Geological Society of America, Boulder, Colo.

Hsü, K.J., Cita, M.B., Ryan, W.B.F., 1973a. The origin of the Mediterranean evaporites. Initial Rep. Deep Sea Drill. Proj. 13, 1203-1231.

Hsü, K.J., Ryan, W.B.F., Cita, M.B., 1973b. Late Miocene Desiccation of the Mediterranean. Nature 242, 240-244. https://doi.org/10.1038/242240a0.

Iaccarino, S.M., Bossio, A., 1999. Paleoenvironment of uppermost Messinian sequences in the Western Mediterranean (site 974, 975, and 978). Proc. Ocean Drill. Program Sci. Results 161, 529-541.

Jiménez-Munt, I., Torne, M., Fernàndez, J., Vergés, J., Kumar, A., Carballo, D., García-Castellanos, D., 2019. Deep seated density anomalies across the Iberia-Africa plate boundary and its topographic response. J. Geol. Res. https://doi.org/10.1029/ 2019JB018445.

Juan, C., Ercilla, G., Javier Hernández-Molina, F., Estrada, F., Alonso, B., Casas, D., García, M., Farran, M., Llave, E., Palomino, D., Vázquez, J.-T., Medialdea, T., Gorini, C., D'Acremont, E., El Moumni, B., Ammar, A., 2016. Seismic evidence of currentcontrolled sedimentation in the Alboran Sea during the Pliocene and Quaternary: palaeoceanographic implications. Mar. Geol. 378, 292-311. https://doi.org/10. 1016/j.margeo.2016.01.006.

Kartveit, K.H., Ulsund, H.B., Johansen, S.E., 2019. Evidence of sea level drawdown at the end of the Messinian salinity crisis and seismic investigation of the Nahr menashe unit in the northern levant basin, offshore Lebanon. Basin Res. 0. https://doi.org/10. 1111/bre.12347.

Krijgsman, W., Stoica, M., Vasiliev, I., Popov, V.V., 2010. Rise and fall of the Paratethys Sea during the Messinian Salinity Crisis. Earth Planet. Sci. Lett. 290, 183-191.

Krijgsman, W., Capella, W., Simon, D., Hilgen, F.J., Kouwenhoven, T.J., Meijer, P.Th., Sierro, F.J., Tulbure, M.A., van den Berg, B.C.J., van der Schee, M., Flecker, R., 2018. The Gibraltar Corridor: watergate of the Messinian Salinity Crisis. Mar. Geol. 403, 238-246. https://doi.org/10.1016/j.margeo.2018.06.008.

Lamb, M.P., Dietrich, W.E., Aciego, S.M., DePaolo, D.J., Manga, M., 2008. Formation of Box Canyon, Idaho, by megaflood: implications for seepage erosion on earth and mars. Science 320, 1067-1070.

Larsen, I.J., Lamb, M.P., 2016. Progressive incision of the channeled scablands by outburst floods. Nature 538, 229-232. https://doi.org/10.1038/nature19817.

Lofi, J., 2010. Atlas of the Messinian Salinity Crisis MSC.

Lofi, J., 2018. The Messinian Salinity Crisis MSC Markers in the Mediterranean Sea Volume 2. Commission for the World Geological Map.

Lugli, S., Manzi, V., Roveri, M., Schreiber, B.C., 2015. The deep record of the Messinian salinity crisis: evidence of a non-desiccated Mediterranean Sea. Palaeogeogr. Palaeoclimatol. Palaeoecol. 433, 201-218. https://doi.org/10.1016/j.palaeo.2015. 05.017.

Madof, A.S., Bertoni, C., Lofi, J., 2019. Discovery of vast fluvial deposits provides evidence for drawdown during the late Miocene Messinian salinity crisis. Geology 47, 171-174. https://doi.org/10.1130/G45873.1.

Manzi, V., Lugli, S., Lucchi, F.R., Roveri, M., 2005. Deep-water clastic evaporites deposition in the Messinian Adriatic foredeep (northern Apennines, Italy): did the Mediterranean ever dry out? Sedimentology 52, 875-902. https://doi.org/10.1111/j. 1365-3091.2005.00722.x.

Marzocchi, A., Flecker, R., Van Baak, C.G.C., Lunt, D.J., Krijgsman, W., 2016. Mediterranean outflow pump: an alternative mechanism for the Lago-mare and the end of the Messinian Salinity Crisis. Geology 44, 523-526. https://doi.org/10.1130/ G37646.1.

Micallef, A., Camerlenghi, A., Garcia-Castellanos, D., Otero, D.C., Gutscher, M.-A. Barreca, G., Spatola, D., Facchin, L., Geletti, R., Krastel, S., Gross, F., Urlaub, M., 2018. Evidence of the Zanclean megaflood in the eastern Mediterranean Basin. Sci. Rep. 8, 1078. https://doi.org/10.1038/s41598-018-19446-3.

Micallef, A., Camerlenghi, A., Georgiopoulou, A., Garcia-Castellanos, D., Gutscher, M.-A., Lo Iacono, C., Huvenne, V.A.I., Mountjoy, J.J., Paull, C.K., Le Bas, T., Spatola, D., Facchin, L., Accettella, D., 2019. Geomorphic evolution of the Malta Escarpment and implications for the Messinian evaporative drawdown in the eastern Mediterranean Sea. Geomorphology 327, 264-283. https://doi.org/10.1016/j.geomorph.2018.11. 012.

O'Connor, J.E., 1993. Hydrology, hydraulics, and geomorphology of the Bonneville flood. Geol. Soc. Am. Spec. Pap. 274.

O'Connor, J.E., Baker, V.R., 1992. Magnitudes and implications of peak discharges from glacial Lake Missoula. Geol. Soc. Am. Bull. 104, 267-279.

Orszag-Sperber, F., 2006. Changing perspectives in the concept of "Lago-Mare" in 
Mediterranean late Miocene evolution. Sediment. Geol. 188-189, 259-277. https:// doi.org/10.1016/j.sedgeo.2006.03.008.

Orszag-Sperber, F., Rouchy, J.-M., Blanc-Valleron, M.-M., 2000. La transition Messinien-Pliocène en Méditerranée orientale (Chypre): la période du Lago-Mare et sa signification. C. R. Acad. Sci. 331, 483-490. https://doi.org/10.1016/S12518050(00)01433-6.

Pardee, J.T., 1942. Unusual currents in Glacial Lake Missoula, Montana. Geol. Soc. Am. Bull. 53, 1569-1600.

Periáñez, R., Abril, J.M., 2015. Computational fluid dynamics simulations of the Zanclean catastrophic flood of the Mediterranean (5.33Ma). Palaeogeogr. Palaeoclimatol. Palaeoecol. 424, 49-60. https://doi.org/10.1016/j.palaeo.2015.02.017.

Periáñez, R., Abril, J.M., Garcia-Castellanos, D., Estrada, F., Ercilla, G., 2019. An exploratory modelling study on sediment transport during the Zanclean flood of the Mediterranean. SN Appl. Sci. 1. https://doi.org/10.1007/s42452-019-0374-y.

Pierre, C., Caruso, A., Blanc-Valleron, M.-M., Rouchy, J.M., Orzsag-Sperber, F., 2006 Reconstruction of the paleoenvironmental changes around the Miocene"Pliocene boundary along a West"East transect across the Mediterranean. Sediment. Geol. 188-189, 319-340. https://doi.org/10.1016/j.sedgeo.2006.03.011.

Rouchy, J.-M., Martin, J.-P.S., 1992. Late Miocene events in the Mediterranean as recorded by carbonate-evaporice relations. Geology 20, 629. https://doi.org/10.1130/ 0091-7613(1992)020<0629:LMEITM > 2.3.CO;2.

Roveri, M., Bassetti, M.A., Ricci Lucchi, F., 2001. The mediterranean Messinian salinity crisis: an Apennine foredeep perspective. Sediment. Geol. 140, 201-214.

Roveri, Marco, Flecker, R., Krijgsman, W., Lofi, J., Lugli, S., Manzi, V., Sierro, F.J., Bertini, A., Camerlenghi, A., De Lange, G., Govers, R., Hilgen, F.J., Habscher, C., Meijer, P.T.,
Stoica, M., 2014a. The Messinian Salinity Crisis: past and future of a great challenge for marine sciences. Mar. Geol. https://doi.org/10.1016/j.margeo.2014.02.002.

Roveri, M., Manzi, V., Bergamasco, A., Falcieri, F.M., Gennari, R., Lugli, S., Schreiber, B.C., 2014b. Dense shelf water cascading and Messinian Canyons: a new scenario for the Mediterranean salinity crisis. Am. J. Sci. 314, 751-784. https://doi.org/10.2475/ 05.2014.03.

Ryan, W.B., 2008. Modeling the magnitude and timing of evaporative drawdown during the Messinian salinity crisis. Stratigraphy 5, 227-243.

Ryan, W.B.F., 2009. Decoding the Mediterranean salinity crisis. Sedimentology 56, 95-136. https://doi.org/10.1111/j.1365-3091.2008.01031.x.

Ryan, W.B.F., Hsu, K.J., Cita, M.B., 1973. Site 120. Initial Rep. Deep Sea Drill. Proj. 13, 19-41.

Selli, R., 1960. Il Messiniano Mayer-Eymar, 1867. Proposta di un neostratotipo. Giorn. Geol., ser. 2, 28: 1-33.

Sternai, P., Caricchi, L., Garcia-Castellanos, D., Jolivet, L., Sheldrake, T.E., Castelltort, S., 2017. Magmatic pulse driven by sea-level changes associated with the Messinian salinity crisis. Nat. Geosci. 10, 783-787. https://doi.org/10.1038/ngeo3032.

Urgeles, R., Camerlenghi, A., Garcia-Castellanos, D., De Mol, B., Garces, M., Verges, J., Haslam, I., Hardman, M., 2011. New constraints on the Messinian sealevel drawdown from 3D seismic data of the Ebro margin, western Mediterranean. Basin Res. 23, 123-145. https://doi.org/10.1111/j.1365-2117.2010.00477.x.

Proceedings of the Ocean Drilling Program, 161 Scientific results. In: Zahn, R., Comas, M.C., Klaus, A. (Eds.), Proceedings of the Ocean Drilling Program. Ocean Drilling Program, https://doi.org/10.2973/odp.proc.sr.161.1999. 